\title{
The Regulation of Entrepreneurial Litigation: Balancing Fairness and Efficiency in the Large Class Action*
}

\author{
John C. Coffee, Jr. $†$
}

\section{INTRODUCTION}

Just as war is too important to be left to generals, civil procedure-with apologies to Clemenceau-is too important to be left to proceduralists. ${ }^{1}$ Although it would be a serious overstatement to claim that all civil procedure scholars are confined by a tunnel vision focused only on the Federal Rules of Civil Procedure, they have as a group been reluctant to engage explicitly in incentivebased reasoning and seem particularly hesitant to reexamine what they must know to be a noble myth: namely, that the client can and should control all litigation decisions. ${ }^{2}$ Within an important and expanding context-one that this article will call that of "entrepreneurial litigation"-this assumption of client control simply does not hold. Instead, the relationship of attorneys to clients within this domain presents a classic illustration of market failure: here, the market for legal services. Much of this article will focus

* $O$ by John C. Coffee, Jr., 1987.

† Adolph A. Berle Professor of Law, Columbia University.

- This article extends my earlier work on plaintiffs' attorneys and the special contexts of securities and derivative class actions to the context of mass disaster cases. See John C. Coffee, Jr., Understanding the Plaintiff's Attorney: The Implications of Economic 'Theory for Private Enforcement of Law Through Class and Derivative Actions, 86 Colum. L. Rev. 669 (1986) ("Plaintiff's Attorney"); John C. Coffee, Jr., The Unfaithful Champion: The Plaintiff as Monitor In Shareholder Litigation, 48 L. \& Contemp. Probs. 5 (Summer 1985) ("Unfaithful Champion"); John C. Coffee, Jr., Rescuing the Private Attorney General: Why the Model of the Lawyer as Bounty Hunter Is Not Working, 42 Md. L. Rev. 215 (1983) ("Private Attorney General").

2 Few doubt that client control will be weak in a large class action involving a dispersed plaintiff class. More controversial is my assertion that within this context, client control is not only illusory, but sometimes undesirable, because the interests of individual clients will typically conflict. See Deborah L. Rhode, Class Conflicts in Class Actions, 34 Stan. L. Rev. 1183 (1982). While some commentators have sought to reestablish client control through alternatives to the class action, see, e.g., Roger H. Transgrud, Joinder Alternatives in Mass Tort Litigation, 70 Cornell L. Rev. 779 (1985), their position ignores the high public costs associated with duplicative, multiforum litigation. The proper question for public policy is how to reduce both public costs and private (or "agency") costs so that the class action does not unfairly subordinate the interests of any group of plaintiffs to another. 
on the various causes of this market failure-that is, high information costs, adverse selection and common pool problems, as well as the legal rules that aggravate these problems-but the more important question involves how the law should respond to the fact of market failure. Clearly, when markets fail, the law must regulate. But how should the law regulate? What goals should be given priority? These are not simple questions, and their difficulty may explain the stubborn devotion of many proceduralists to the ideal of individual client control. Even a failed and quixotic model may offer more hope than an intellectual void, and few have offered clear conceptual alternatives to the ideal of client control.

One such conceptual alternative, however, has recently been proposed in the context of mass tort litigation. Professor David Rosenberg has sketched an egalitarian vision of "bureaucratic justice" under which the class action would be rationalized by legal rules that seek to standardize damages and adjudicate all claims in one mandatory class action. ${ }^{3}$ Though intellectually coherent and powerful, this model of regulation is the polar opposite of client control and has costs for some clients that have not been sufficiently recognized. In particular, mandatory classing and damage averaging focus our system of justice on the interests of the average plaintiff and ignore differences among the merits of various plaintiffs' claims.

If we are hesitant about encouraging the wealth transfers that such a system of regulation tends to produce, we must face a difficult question: Is there any sound alternative to "bureaucratic justice" given our initial assumption that individual client control is infeasible within this context? This article will examine an alternative regulatory approach: inducing attorneys to mimic the results that a healthy, functioning market for legal services would produce. "Mimicking the market" as a regulatory strategy requires not that clients be able to bargain in fact but that we be able to manipulate the incentives that the law holds out so as to motivate attorneys to perform as we believe informed clients would want them.

To raise this alternative to the bureaucratization of class actions is not necessarily to endorse it wholly. Important tradeoffs must be faced between public costs (which multiple proceedings

s See David Rosenberg, The Causal Connection in Mass Exposure Cases: A "Public Law" Vision of the Tort System, 97 Harv. L. Rev. 849 (1984); David Rosenberg, Class Actions for Mass Torts: Doing Individual Justice by Collective Means, 62 Ind. L. J. 561 (1987) (forthcoming). 
maximize and mandatory classing under a system of bureaucratic regulation minimizes) and the private costs (or "agency costs") stemming from the attorney-client relationship (which a marketmimicking strategy should minimize). To explore these tradeoffs, it is useful to look beyond the immediate context of civil litigation to functionally analogous settings where similar problems arise, such as bankruptcy reorganizations and labor negotiations. Remote as these contexts may seem at first glance, they also involve large and unstable coalitions of parties who hold claims against a common adversary: the corporate debtor in reorganization proceedings and the employer in labor negotiations. Although the answers that have been developed to deal with the problem of internal dissension in these contexts may not be easily generalized, they nonetheless illustrate the common problems involved when individuals must undertake collective action, and they demonstrate the need for similarly distinctive answers in the class litigation context.

Part I of this article defines the context of "entrepreneurial litigation" and argues that a variety of problems familiar to law and economics scholarship-for example, agency costs, free riders, rent-seeking, and common pool problems-produce a misalignment of incentives that hobbles private enforcement of law through class action litigation. As a result, the settlement value of an action often has little relationship to its underlying merits."

Part II focuses on the entrepreneurial plaintiff's attorney and explores important and often neglected tradeoffs presented in class actions between the goals of efficiency and distributive fairness. The economic self-interest of the plaintiff's attorneys may lead them to treat all plaintiffs in the class as if their claims had roughly equivalent settlement values. This tendency to ignore the variance within the class helps explain the tensions within the large class action and the behavior of those who resist class certification. The most effective recourse of the individual plaintiff who possesses a claim of above average settlement value is to "opt out" of the class and pursue an individual action. ${ }^{5}$ At this point, the

4 For discussion of the factors in entrepreneurial litigation that can relegate the litigation merits to a level of secondary significance, see Plaintiff's Attorney (cited in note 1). See also part I-D (at notes $35-38$ ). I thus find incomplete those economic models of litigation that assume that the parties will settle as soon as they can reach a common estimate of the litigation odds. See, e.g., George L. Priest and Benjamin Klein, The Selection of Disputes for Litigation, 13 J. Legal Stud. 1, 12-15 (1984).

- The plaintiff cannot opt out of the class if the action can be brought under Rule 23(b)(1) or (b)(2) of the Federal Rules of Civil Procedure. See Fed. Rule Civil Proc. 23(c)(3). However, most class actions for financial damages are brought under Rule 23(b)(3), which 
interests of efficiency and fairness collide. Public and private litigation costs "increase exponentially as the number of parties increases." In addition, multiple actions create the conditions for a recurring phenomenon that this article calls the "rush to judgment," which defendants can often exploit. As a result, commentators have called for mandatory class actions from which plaintiffs could not opt out. ${ }^{7}$ Yet, these commentators overlook countervailing considerations of fairness. The litigation merits and settlement values of the claims consolidated in the large class action vary widely, especially in mass tort actions. ${ }^{8}$ Given this variance, the cost of mandatory consolidation falls most heavily on those with claims of above average value-typically those most seriously injured.

Further complicating this efficiency/fairness tradeoff is the behavior of some plaintiffs' attorneys. At first glance, the frequent resistance of plaintiffs' attorneys to class certification ${ }^{9}$ may seem

permits certification if "the court finds that the questions of law or fact common to the members of the class predominate over any questions affecting only individual members, and that a class action is superior to other available methods for the fair and efficient adjudication of the controversy." Plaintiffs may opt out from a Rule 23(b)(3) action. See Reynolds v. National Football League, 584 F.2d 280, 283 (8th Cir. 1978), comparing Rule 23(b)(1) and $23(b)(3)$.

If a class action may not be maintained, the separate individual actions may still be consolidated for pretrial proceedings, under the multidistrict panel statute. See 28 U.S.C. $\S 1407$ (a) (1986). Plaintiffs are not permitted to opt out from this consolidated proceeding, which does not deprive them of their right to an individual trial. For an overview, see Note, The Judicial Panel and the Conduct of Multidistrict Litigation, 87 Harv. L. Rev. 1001 (1974). While $\S 1407$ (a) contemplates that upon completion of the pretrial proceedings the individual actions will be remanded to their original districts, the experience has been that such remands do not in fact occur. Rather, the transferee court resolves all issues. See Comment, The Experience of Transferee Courts Under the Multidistrict Litigation Act, 39 U. Chi. L. Rev. 588, 607-08 (1972).

B See Richard A. Epstein, The Legal and Insurance Dynamics of Mass Tort Litigation, 13 J. Legal Stud. 475, 477 (1984).

7 For well-argued statements of this view, see Note, Class Certification in Mass Accident Cases Under Rule 23(b)(1), 96 Harv. L. Rev. 1143 (1983); Rosenberg, 97 Harv. L. Rev. at 913 (cited in note 3). Similarly, Judge Jack Weinstein has called for a "National Disaster Court" and for enhanced power in the Judicial Panel on Multidistrict Litigation to consolidate state and federal cases. See Jack B. Weinstein, Preliminary Reflections on the Law's Reaction to Disasters, 11 Colum. J. Envtl. L. 1, 44-47 (1986). For other statements of the need for an improved "mass tort" class action, see Comment, The Use of Class Actions for Mass Accident Litigation, 23 Loyola L. Rev. 383 (1977).

${ }^{8}$ See, for example, Epstein, $13 \mathrm{~J}$. Legal Stud. at 479-80 (cited in note 6); Weinstein, 11 Colum. J. Envtl. L. at 8-12 (cited in note 7). Sometimes, the variance is sufficiently great that the court may refuse to certify the class. See In re Northern Dist. of Cal, Dalkon Shield, Etc., 693 F.2d 847 (9th Cir. 1982).

${ }^{9}$ See David Lauter, Dalkon Shield Cases Thrown Into Disarray, Nat'l L. J. p. 1, col. 3 and p. 10, col. 1 (Mar. 17, 1986) (noting recent disputes among plaintiffs' attorneys in mass tort class actions); Emily Couric, The A. H. Robins Saga, 72 A.B.A. J. 56 (July 1, 1986). 
puzzling, because the class action traditionally served to increase the plaintiff's bargaining power against larger, wealthier defendants. ${ }^{10}$ One explanation for this pattern is that just noted: some plaintiffs may believe they can do better in an individual action. Another, less polite explanation is that the attorneys can do better in individual actions (even if their clients cannot) because the compensation they can expect under the contingent fee system used in individual actions will be higher than their expected fee award in a large class action. ${ }^{11}$ The conflict here between the interests of attorney and client thus underscores the fallacy in the traditional assumption of individualized client control. Too often this uncontroversial normative premise may mask a darker reality that we tend to repress because we cannot imagine an acceptable alternative approach.

Part III of this article considers some of the numerous proposals for reform of class action litigation. ${ }^{12}$ It finds most such propos-

10 See Note, 96 Harv. L. Rev. at 1144-45 (cited in note 7).

$"$ See id. at 1148. Contingent fees in mass accident litigation often reach 40 percent of the recovery. See Randal R. Craft, Jr., Factors Influencing Settlement of Personal Injury and Death Claims in Aircraft Accident Litigation, 46 J. Air L. \& Commerce 895, 919 (1981). The individual attorney may represent several plaintiffs in the same disaster and charge the same percentage fee to each plaintiff, without reducing the fee to reflect the obvious economies of scale in joint litigation. In contrast, in a federal class action, the court must approve the fee award and will probably use the "lodestar formula," which bases the fee on the attorney's time reasonably expended in the action. See notes 27-29 and accompanying text.

12 Many of these proposals seek either to reduce damages or attorneys fees. See, e.g., Report on Treble Damages, 40 Record of the Association of the Bar of the City of New York 647, 660 (1985). The Reagan Administration has endorsed proposals to limit jury awards and attorney's fees. See Robert Pear, Administration Submits Plan to Reduce Damage Awards, N.Y. Times B9, col. 1 (May 1, 1986). The American Bar Association's McKay Commission has, however, concluded that "regulating attorneys' fees is an inappropriate strategy for accomplishing" tort reform. See American Bar Association, Report of the Action Commission to Improve the Tort Liability System 26 (1987); E. R. Shipp, A.B.A. Split Over Proposals to Revise Tort System, N.Y. Times 12, col. 3-6 (Feb. 16, 1987). Several recent Supreme Court decisions nonetheless show the Court willing to chill litigation by reducing fee awards, either by legitimating fee waivers, see Evans v. Jeff D., 106 S.Ct. 1531 (1986), expanding the scope of Rule 68 of the Federal Rules of Civil Procedure, see Marek v. Chesny, 473 U.S. 1 (1985), or restricting fee enhancements for the merit or skill of the plaintiffs' attorneys, see Pennsylvania v. Delaware Valley Citizens' Council, 106 S.Ct. 3088 (1986). Most recently, the Court has sharply curtailed the ability of federal courts to award risk multipliers to reflect the risk of nonpayment under a contingent fee formula. See Pennsylvania v. Delaware Valley Citizens' Council, 107 S.Ct. 3078 (1987).

Others have advanced proposals intended to reduce the proliferation of multiforum litigation. In particular, the Reporters to the American Law Institute have focused on modifications to the traditional law of preclusion in order to discourage plaintiffs from opting out of class actions by denying them the benefits of offensive collateral estoppel while making them subject to defensive collateral estoppel. See American Law Institute, Preliminary Study of Complex Litigation 177-80 (Draft Report for Council, Dec. 1, 1986). See also Thomas Rowe and Kenneth Sibley, Beyond Diversity: Federal Multiparty, Multiforum Ju- 
als at best to have made only weak attempts to manipulate the incentives the law holds out to the plaintiff's attorney and instead to have placed excessive reliance on monitoring devices-such as special guardians or expanded settlement hearings. Accordingly, Part III attempts to map the available options by which to regulate the sensitive "opt out" decision from a "market mimicking" perspective.

\section{The Dynamics of Class Action Litigation}

Commentary about complex civil litigation tends to subdivide the field into specialized contexts: antitrust class actions, products liability cases, securities litigation, "mass disaster" cases, civil rights litigation, etc. Although this taxonomy allows each expert to stress the uniqueness of her own context, it obscures the common denominators among subcategories. Most attorneys today probably would concede that derivative, securities, and antitrust litigation are contexts in which the plaintiff"s attorney functions in an "entrepreneurial" mode, but they might resist such a description of mass tort or products liability litigation. Yet any attempt to draw categorical lines among these contexts is unwise. Without denying that antitrust litigation differs from, for example, toxic tort cases in important respects, this section will stress three generalizations about large class actions that apply, with varying degrees of force, to each of these subcategories:

- High agency costs characterize class action litigation and permit opportunistic behavior by attorneys. As a result, it is more accurate to describe the plaintiff's attorney as an independent entre-

risdiction, 135 U. Pa. L. Rev. 7 (1986).

Much law review commentary has emphasized other procedural reforms, such as stricter pleading requirements, expanded hearings at the settlement approval stage, or the appointment of special guardians. Compare Richard L. Marcus, The Revival of Fact Pleading Under the Federal Rules of Civil Procedure, 86 Colum. L. Rev. 433 (1986); Note, Abuse in Plaintiff Class Action Settlements: The Need for a Guardian During Pretrial Settlement Negotiations, 84 Mich. L. Rev. 308 (1985); Note, Derivative Suit Settlements: In Search of a New Lodestar, 48 L. \& Contemp. Probs. 229 (Summer 1985).

Although persuasive cases can be made for all these procedural reforms (especially those that reduce costly multiforum litigation), the impact of such procedural changes on the entrepreneurially motivated plaintiff's attorney seems likely to be marginal at best. In general, these proposals place overly optimistic reliance on the monitoring capabilities of the court and ignore the economic incentives that produce multiforum litigation and opting out. In contrast, the Supreme Court's recent decisions on fee awards could have great impact, but are heavy-handed attempts to bludgeon the plaintiff's attorney. 
preneur than as an agent of the client.

- Class actions necessarily involve asymmetric stakes. Defendants are prepared to expend greater resources on the prosecution of the action than are plaintiffs' attorneys, because defendants have more to gain or lose.

- An initial cost differential tends to favor plaintiffs in many forms of class action litigation, thereby inviting the filing of actions with a low prospect of success at trial. While this factor may sometimes offset or overcome the asymmetric stakes factor, its significance erodes during the course of the litigation.

These three problems-high agency costs, asymmetric stakes, and cost differentials-are not the only generalizations that one can advance about class actions, but they apply with considerable force over the greatest range of actions and, in conjunction, may dwarf the litigation odds as determinants of a case's settlement value.

\section{A. The Agency Cost Problem}

It is no secret that substantial conflicts of interest between attorney and client can arise in class action litigation. ${ }^{13}$ In the language of economics, this is an "agency cost" problem. ${ }^{14}$ All principal-agent relationships give rise to agency costs, which consist of (1) the costs of monitoring the agent, (2) the costs the agent incurs to advertise or guarantee his fidelity ("bonding" costs), and (3) the residual costs of opportunistic behavior that it is not cost-efficient to prevent. The classic agency cost problem in class actions involves the "sweetheart" settlement, in which the plaintiff's attorney trades a high fee award for a low recovery. The principal-agent relationship also encourages subtler forms of opportunism such as "shirking"-where the attorney fails to expend the effort she otherwise would have put forth had the client been capable of actively monitoring the litigation. Conversely, the attorney may seek to provide additional services that are not desired by the client. For

${ }^{13}$ For classic statements on this problem by Judge Friendly, see Alleghany Corp. v. Kirby, 333 F.2d 327, 347 (2d Cir. 1964) (dissent); Saylor v. Lindsley, 456 F.2d 896, 899-900 (2d Cir. 1972). See also Andrew Rosenfield, An Empirical Test of Class-Action Settlement, 5 J. Legal Stud. 113, 114-17 (1976) (statistical tests show that class action settlements result in pecuniary gains to attorneys at the expense of the class).

"See Michael C. Jensen and William H. Meckling, Theory of the Firm: Managerial Behavior, Agency Costs and Ownership Structure, 3 J. Fin. Econ. 305 (1976); Eugene F. Fama, Agency Problems and the Theory of the Firm, 88 J. Pol. Econ. 288 (1980). 
example, it has been suggested that plaintiffs' attorneys may seek to structure a "fluid recovery," which provides for price discounts or distributions in kind to future class members, because the administration of such a remedy can bring additional fees to the plaintiff's attorney. ${ }^{18}$

Although the theory of agency costs is well-known, its application in the class action context is distinctive in several respects. The members of the plaintiff class usually have very little capacity to monitor their agents. While one could make this observation about individual shareholders, who also are widely dispersed and have too small an investment to justify monitoring corporate managers, several factors exacerbate agency problems in the market for legal services. First, the information costs tend to be higher because the critical decisions in litigation typically have lower visibility and require greater expertise to understand than in the case of the shareholder-manager relationship, where a mandatory disclosure system and the financial press at least supply a limited basis for comparison.

Second, in many settings, few plaintiffs expect a recovery sufficient to justify the cost of monitoring. Although some plaintiffs in a mass tort action may have suffered disproportionately large injuries and thus have a sufficient stake in the action to justify expending funds to monitor the attorney, most do not. These other plaintiffs who have sustained relatively small injuries, however, can "free ride" on the monitoring efforts of these "higher stake" plaintiffs. Collectively, the result is underinvestment in monitoring expenditures.

${ }^{10}$ For a discussion of "fluid recoveries," see Developments in the Law-Class Actions, 89 Harv. L. Rev. 1318, 1516-36 (1976). When the plaintiffs are so numerous and the individual recovery so small that many eligible victims will not claim their share of the settlement fund, courts may approve settlements where the defendants make price concessions or offer rebates to all persons who may have been injured. Coupons may, for example, be issued to all persons owning an item whose price had been illegally fixed, entitling them to a discount on their purchase of a replacement. See, e.g., Colson v. Hilton Hotel Corporation, 59 F.R.D. 324 (N.D. Ill. 1972) (hotel chain agrees to lower room rates for defined period because specific victims of price fixing were not feasibly identifiable). Sometimes, such "fluid recoveries" are necessary, but they may also sometimes mask attorney opportunism. The more complex and involved the procedure, the greater the chance for the plaintiff's attorney to institutionalize herself in a trustee-like role overseeing its operation while billing fees out of the settlement fund. See Thomas R. Meites and Sargent L. Aborn, Distributing the Settlement Fund in a Class Action, 7 Litigation 33, 34 (Summer 1981) (advising class counsel to structure settlements so that they could serve as administrators of payment disbursement plans). But see In re Folding Carton Antitrust Litig., 744 F.2d 1215 (7th Cir. 1984) (court rejected use of unclaimed portion of settlement fund to create an "Antitrust Development and Research Foundation" to promote study of antitrust law). 
Third, no public market exists in the case of the attorney-client relationship to motivate the attorney to serve the client's interests. Shareholders, for example, can reduce the managers' incentive to act opportunistically by compensating them through stock options and other devices that align the interests of the two groups. By contrast, because one cannot trade interests in a lawsuit like shares of stock, no informed and active market can discipline or motivate the agents in the litigation context.

Finally, the most basic characteristic of a market is lacking within the context of entrepreneurial litigation because the buyer does not shop for legal services. Rather than the "principal" hiring the "agent," the reverse often occurs with the attorney finding the client after the attorney first researches and prepares the action. In securities and derivative litigation, the phenomenon of "in house" plaintiffs-namely, clients who are virtually satellites of a particular firm-has long been known, but today even in mass disaster cases the same plaintiff may turn up as the class representative in totally unrelated cases. ${ }^{16}$ The extreme example of trivializing the role of the client is the "professional plaintiff" who has appeared in literally hundreds of other actions ${ }^{17}$ or another attorney with whom a reciprocal relationship exists. ${ }^{18}$ In mass tort cases, a differ-

${ }^{16}$ See James B. Stewart, Wake of Disaster: Controversy Surrounds Payments to Plaintiffs in Hyatt Regency Case, Wall St. J. 1, col. 1 (July 3, 1984) (noting that plaintiff Deborah Jackson, the only plaintiff able to establish diversity jurisdiction in the class actions growing out of the collapse of the Hyatt skywalk in Kansas City, Missouri, was also the plaintiff in the class actions stemming from the MGM Grand Hotel fire in Las Vegas, Nevada). This appears to be an illustration of the curious "underground railroad" by which plaintiffs' attorneys can locate and obtain the services of a valuable plaintiff who can establish standing, diversity jurisdiction, or some other important element of the case. Mrs. Jackson did not sustain any apparent physical injury in the skywalk collapse, but did receive $\$ 172,500$ in damages. Id.

17 The legendary case is Harry Lewris, a retired attorney who since 1971 has "filed nearly 100 shareholder actions in Manhattan Federal District Court and close to fifty in [New York] state court." See Shereff, "The Constant Suitor," Manhattan, Inc. (May 1986). Mr. Lewis has also been similarly active in Delaware. See Richard B. Schmitt, Attorneys Are Often Big Winners When Shareholders Sue Small Companies, Wall St. J. 31, col. 1 (June 12, 1986). See also Marcus, 86 Colum. L. Rev. at $474-75$ (cited in note 12) (forty-three federal actions by end of 1984 in which $\mathrm{Mr}$. Lewis was a named plaintiff). Mr. Lewis does not stand alone. His closest rival today would appear to be Mr. William Weinberger, who had "roughly thirty suits" pending as a plaintiff as of June, 1986. See Schmitt, Wall St. J. at 31 (June 12, 1986).

${ }^{18}$ See, for example, Lowenschuss v. Kane, 520 F.2d 255, 259 n.2 (2d Cir. 1975) (plaintiff was attorney whose firm's pension plan invested in takeover target); Tanzer v. International General Industries, Inc., 379 A.2d 1121 (Del. 1977) (plaintiffs were trustees of "Tanzer Economic Associates, Inc. Profit Sharing Plan"). Obviously, a pension or profit-sharing plan as a client gives an attorney access to a broadly diversified portfolio of stocks and thus makes it more economic to incur search costs. 
ent pattern has emerged: increasingly, the lead counsel may engage in a nationwide solicitation for eligible plaintiffs, as in the Agent Orange action. ${ }^{19}$ In the Bhopal litigation, for example, one American attorney managed to obtain retainer agreements from over 7,000 individual clients in less than a week; ${ }^{20}$ other individual attorneys claimed to represent as many as 57,000 clients. ${ }^{21}$ While one may wish to believe that client solicitation on such massive scale could not occur within the United States, where legal rules against solicitation have long been the norm, ${ }^{22}$ the facts of the Dalkon Shield litigation suggest otherwise. There, two plaintiffs' attorneys assembled some 900 individual clients in a relatively brief period. ${ }^{23}$ Moreover, new techniques for massive screening and solicitation of clients are emerging. In the burgeoning asbestos litigation, plaintiffs' attorneys have entered into arrangements with labor unions and medical clinics to implement "dragnet medical screenings" and "direct-mail solicitations" that have yielded literally thousands of new cases-apparently without offending legal ethics standards because the solicitations took place at the behest of a union or social welfare agency. ${ }^{24}$

From an entrepreneurial perspective, such solicitation techniques represent imaginative marketing and aggressive "new-product development." "25 More importantly, they also show the futility of an individual client control model. Indeed, the retainer agreement in such a context begins to resemble the traditional contract of adhesion. Although in some circumstances the plaintiff class may have a sufficiently close preexisting relationship among them-

19 See Peter H. Schuck, Agent Orange on Trial: Mass Toxic Disasters in the Courts 47 52 (1986) (describing a cross-country journey by Victor Yannaconne, who initiated the Agent Orange litigation, during which he sought out veterans who had arguably experienced injuries from exposure to the chemical). See also In re Agent Orange Product Liability Litigation, 611 F.Supp. 1296, 1301-02 (E.D.N.Y. 1985), aff'd in part, rev'd in part, 818 F.2d 216 (2d. Cir. 1987).

${ }^{20}$ See David T. Austern, Is Lawyer Solicitation of Bhopal Clients Ethical?, Legal Times 16 (Jan. 21, 1985); Bhopal Lawyer Disbarred, Amer. Lawyer 79 (May 1985); Deborah L. Rhode, Solicitation, 36 J. Legal Educ. 317, 319 (1986).

${ }^{21}$ Rhode, 36 J. Legal Educ. at 319 (cited in note 20).

${ }^{22}$ See Ohralik v. Ohio State Bar Assn., 436 U.S. 447 (1978); ABA Model Rules of Professional Conduct, Rule 7.3 (1983).

${ }^{23}$ Paul Blustein, How Two Young Lawyers Got Rich by Settling IUD Liability Claims, Wall St. J. 1, col. 1, (Feb. 24, 1982).

${ }^{24}$ Bill Richards and Barry Meier, Widening Horizons: Lawyers Lead Hunt for New Groups of Asbestos Victims, Wall St. J. 1, col. 6 (Feb. 18, 1987) (examples including lawyers renting vans with mobile $\mathrm{X}$-ray units to test tire workers at seventy-two union locals nationwide, resulting in "nearly 1,000 new asbestos lawsuits with thousands more being readied").

${ }^{25}$ Id. 
selves to be able to select its own attorney, such client cohesion will be unusual in mass tort cases because the victims of dangerous products, airplane accidents, toxic torts or similar events seldom have much in common besides their injury.

For policy purposes, the important fact about client solicitation is not that it is unseemly, but that it distinguishes the market for legal services from other markets where clients are also uninformed but where market failures do not result. For example, the market for medical services is also one where clients tend to lack sophistication. Still, patients make better monitors than class action plaintiffs because the stakes are potentially higher. In addition, patients can rely on medical intermediaries (such as the family doctor) to make a sound referral decision. As a result, medical specialists probably have a stronger incentive to invest in reputational capital in order to attract the attention of these intermediaries. In this light, the evil in client solicitation is not aggressive marketing, but that direct solicitation short circuits the possibility that an informed referral process might develop, as it has in the medical profession.

Market failure is not inevitable even when clients lack information and cannot acquire expert assistance. Other means still exist by which to reduce agency costs, including most importantly compensation formulas. For example, even uninformed clients can align their attorney's interests with their own by compensating them through a percentage-of-recovery fee formula, which is the functional analogue of the stock option device. While this fee arrangement does give the attorney an interest in maximizing the size of the recovery (and thus automatically guards against collusive "sweetheart" agreements), the percentage-of-recovery fee has its own inherent imperfection. Economic analysis suggests that it leads to "premature" settlements that properly informed clients would have rejected. ${ }^{26}$

In any event, at least in federal courts, the percentage-of-recovery fee has been largely superseded by the "lodestar formula," which essentially compensates the plaintiff's attorney based on the time she reasonably expended on the action. ${ }^{27}$ Obviously, the lode-

26 See Plaintiff's Attorney at 686-90 (cited in note 1). For earlier demonstrations of this point, see Kevin M. Clermont and John D. Currivan, Improving on the Contingent Fee, 63 Cornell L. Rev. 529, 544 (1978); Murray L. Schwartz and Daniel J. B. Mitchell, An Economic Analysis of the Contingent Fee in Personal-Injury Litigation, 22 Stan. L. Rev. 1125, 1136 (1970).

${ }^{27}$ The "lodestar formula" was recognized by the Supreme Court in Hensley v. Eckerhart, 461 U.S. 424, 433 (1983), as the most useful method for the determination of fee 
star creates an incentive for delay. ${ }^{28}$ Once time is equated with money, unmonitored lawyers have reason to engage in "makework" or overstaffing. Equally important, the lodestar formula also creates a strong incentive for cheap settlements on the eve of the trial. By that point, the attorney typically has expended nearly all of the time that determines her compensation and has no logical reason to accept the risks of going to trial; a larger recovery for the client will not substantially affect her own fee award. ${ }^{29}$

Given these obvious deficiencies, why has the lodestar formula largely replaced the traditional percentage-of-recovery formula? The lodestar's appearance probably owes much to new forms of litigation-most notably, civil rights and environmental litigation-where there was seldom a monetary recovery. But its spread to contexts where monetary recoveries are at the heart of the litigation requires a different explanation. Cynics might advance an interest group or "capture" theory: namely, that lawyers have conspired to adopt the formula that maximizes their fees and discretion. Still, the lodestar formula is far from popular among plaintiff's attorneys, many of whom would prefer a percentage formula. In this light, the key reason for the lodestar's popularity involves the persistence of legal culture, even in the face of abundant evidence of inefficiency. Put simply, the legal system is comfortable with compensating the plaintiff's attorney on an hourly basis and uncomfortable with a percentage system; the former system treats the plaintiff's attorney the same as all other attorneys, while the latter recognizes that he is in fact a "bounty hunter"-in effect, an independent entrepreneur. The persistence of the lodestar formula may owe much to a desire to repress this evident reality. Still, the consequence of the lodestar is not just to affect private costs, but

awards in fee shifting cases. But see Blum v. Stenson, 465 U.S. 886, 900 n.16 (1984) (indicating that a percentage fee is normally to be used in common fund cases). Originally, the court could enhance the lodestar formula's time component with additional bonuses to reflect the attorney's special skill or the risk inherent in the action. But the Court rejected skill-related bonuses in Delaware Valley Citizens' Council, 106 S.Ct. 3088, and the plurality opinion on reargument, $107 \mathrm{~S}$.Ct. 3078 , would preclude risk factor enhancements. See note 12 . Hence, it appears increasingly to be the case that the attorney's time multiplied by his usual hourly rate will determine the lodestar fee award (at least in fee shifting cases). For a fuller explanation of the lodestar formula, see John Leubsdorf, The Contingency Factor in Attorney Fee Awards, 90 Yale L. J. 473, 477-82 (1981).

${ }^{28}$ See Unfaithful Champion at 33-40 (cited in note 1).

29 Even if an extended trial will result in substantial billable time, the validity of this point is undimmed. The same incentive to enter into a cosmetic settlement will again become strong toward the conclusion of the trial, before the judge or jury reaches its verdict. By definition, there is always a point before judgment at which an attorney compensated on a time basis alone will find it in her rational self-interest to settle. 
public costs as well. Inherently, it requires a bureaucratic procedure for its implementation. Viewed in this light, a court in determining fee awards is functioning essentially as a public utility commission does in setting the fair return for a regulated monopoly. This process is both costly and unnecessary because no individual attorney holds monopoly power. Moreover, the court's own incentives to monitor are open to serious question..$^{30}$ Rather than monitor each individual fee application, courts could adopt tariff schedules that factored in a variety of variables-thereby saving both their time and the client's. This sensible answer would, however, require courts to recognize the reality of entrepreneurial litigation.

\section{B. Asymmetric Stakes}

In most litigation-as in poker-one side's winnings are the other side's losses; the stakes are thus equal, absent special factors. However, once we recognize that the attorney frequently is an independent entrepreneur in class action litigation, it follows that in this context the litigation stakes will be unequal. The defendants have at risk their potential liability plus their legal expenses, while the plaintiffs' attorneys' stake is simply the excess of their expected fee award over those costs that are not separately reimbursable. Evidence suggests that the fee award in most class action litigation is a decreasing function of the recovery, averaging 20 to 30 percent of smaller recoveries and declining further once judgments enter the multimillion dollar range. ${ }^{31}$ This pattern seems to hold

so Judge Friendly phrased this point elegantly in his famous remark that "[a]ll the dynamics conduce to judicial approval of such settlements" once the adversaries have locked arms and approached the court. See Alleghany Corp., 333 F.2d at 347 (dissent). Empirical evidence also supports this conclusion. See Rosenfield, 5 J. Legal Stud. at 114-17 (cited in note 13). Indeed, many courts seem to take very lightly their obligation to review the settlement. See In re Warner Communications Secur. Litig., 618 F.Supp. 735, 740 (S.D.N.Y. 1985) ("In deciding whether to approve this settlement proposal, the court starts from the familiar axiom that a bad settlement is almost always better than a good trial."). For a critique of the result in Warner Communications, see Plaintiff's Attorney at $719 \mathrm{n} .134$ (cited in note 1).

31 Empirical surveys of class actions recurrently report statistics in the 20 to 30 percent range, whatever the fee formula used. See Robert T. Mowrey, Attorney Fees in Securities Class Action and Derivative Suits, 3 J. Corp. L. 267, 334-38, 345-47, 358 (1978); Douglas G. Cole, Counsel Fees in Stockholders' Derivative and Class Actions-Hornstein Revisited, 6 U. Rich. L. Rev. 259, 273-75, 281 (1972) (fee awards average 20 percent and decline as recoveries increase). For a more recent review of fee awards in securities class actions litigated in the Second Circuit, which also finds most awards to fall within the 20 to 30 percent range, see Warner Communications, 618 F.Supp. at 749-50. If the attorney within a specific litigation context expects a fee of 25 to 30 percent based on past experience, a weak de facto percentage-of-recovery system may still be in operation. 
whatever fee formula is used. This 20 to 30 percent benchmark for fee awards thus means, for example, that in litigation where the defendant expects a loss of $\$ 1$ million plus litigation expenses, the plaintiff's' attorneys can expect recovery of $\$ 200,000$ to $\$ 300,000$ at most-minus those costs they incur that will not be reimbursed.

This asymmetry in the litigation stakes can have profound consequences on the willingness of the parties to expend funds on the action. The defendants in the foregoing example would rationally spend up to $\$ 999,999$ to avert the $\$ 1$ million expected loss, but-unless a statutory provision for fee shifting applies-the plaintiffs' attorneys will be unwilling to invest more than $\$ 299,999$ to earn the expected fee of $\$ 300,000$. Admittedly, successful plaintiffs can expect reimbursement of some of their litigation expenses, but the attorneys' major expense is the opportunity cost of their time and effort. The expected fee award still sets an upper bound on their willingness to invest time and effort on the action.

This asymmetry is not inherent in the concept of a contingent fee, but rather is a consequence of judicial regulation. In effect, an individual client might strike a bargain with her attorney in which the fee was wholly contingent but could amount to 99 percent of the recovery. This would be no more irrational than a defendant paying $\$ 99$ in legal expenses to avert a $\$ 100$ loss. Still, because courts recognize that meaningful bargaining is unlikely to occur between a lead counsel and a dispersed plaintiff class, courts have established their own fee formulas which "protect" the class by denying them the ability to enter into "expensive" contracts for legal services. ${ }^{32}$ Although such paternalism is both fully understandable and to a degree justified, it allows defendants to procure more costly legal services than plaintiffs. Accordingly, we should generally expect class action defendants to be willing to litigate more vigorously, to expend more resources, to pursue more collateral matters, and to raise the "ante" at each stage of the litigation in order to exploit this differential.

${ }^{32}$ Alternative fee arrangements include the use of an increasing percentage-of-recovery formula, see Plaintiff's Attorney at 696-97 (cited in note 1), or auction bidding procedures. Imperfections also exist with these formulas, however, because, for example, the lowest bidder may simply have the lowest opportunity costs or the greatest willingness to enter into collusive settlements. As discussed below in the text at note 133, a ceiling on the maximum percentage that the fee award can equal also reduces public costs and serves as a crude quality control against "long shot" actions. 


\section{The Cost Differential}

Litigation may not be equally costly to both sides. Cost differentials, for example, may offset the defendants' ability to outbid the plaintiffs for legal services in the manner described above. Professors Rosenberg and Shavell have offered a formal model of the nuisance suit that depends upon plaintiffs' ability to exploit a significant cost differential. ${ }^{33}$ For instance, if the plaintiffs know that by spending $\$ 10,000$ they can cause the defendants to spend $\$ 100,000$ to have the action dismissed, the action has a settlement value even if it is frivolous on the merits. Much about the nature of civil discovery corroborates the existence of a cost differential. For example, it is far simpler to demand that the defendants identify and furnish all documents, memoranda, letters, and conversations pertaining to a particular matter over a multiyear period than it is to comply with such a demand. That plaintiffs can use discovery to punish their adversaries does not alone imply a cost differential, because defendants in turn can seek discovery of plaintiffs and their witnesses. Yet in most class action litigation, there is relatively little to be learned from the lead plaintiff. Although the defendants can challenge the plaintiff's ability to represent the class, this usually involves a fairly perfunctory inquiry. ${ }^{34}$ For example, in the typical securities class action, there is no dispute that the plaintiff bought the relevant securities, nor in the typical toxic tort case is there doubt that the plaintiff suffered some injury. The extent of individual injury is not especially relevant to being a class representative. Finally, if the plaintiff's' attorneys have lower opportunity costs than the defendants' attorneys, there is inherently a cost differential, even if they perform the

ss David Rosenberg and Steven Shavell, A Model in Which Suits Are Brought for Their Nuisance Value, 5 Int'l Rev. L. \& Econ. 3 (1985).

st Historically, courts have tended to view skeptically the defendant's claim that a conflict of interest renders the lead plaintiff incapable of providing effective representation for the class. See, for example, Tyco Laboratories, Inc. v. Kimball, 444 F.Supp. 292, 299 (E.D. Pa. 1977); Shamrock Associates v. Horizon Corp., 632 F.Supp. 566, 570-71 (S.D.N.Y. 1986). But see Charles A. Wright, Arthur R. Miller, and Mary K. Kane, 7A Federal Practice and Procedure $\$ 1796.1$ (2d ed. 1982) (noting that courts will today consider the adequacy of counsel in evaluating the ability of the class representative to represent the class). Such a focus on the attorney, rather than the client, is consistent with this article's view that courts should accept openly, and deal more realistically with, the reality of entrepreneurial litigation. Some decisions, however, have denied class certification because the class plaintiff lacked sufficient knowledge about the action and tended to defer to the attorney with respect to all litigation decisions. See, e.g., Mills v. Esmark, Inc., 573 F.Supp. 169, 176-77 (N.D. Ill. 1983). Such decisions reflect the continuing and unfortunate inability of some courts to face the fact of entrepreneurial litigation. 
same tasks at an identical pace.

Still, using a cost differential as the starting point for policy analysis seems questionable. The problem in any given case involves the difficulty of determining whether a litigation cost differential is itself a cause or only an effect. Even if plaintiffs' attorneys tend to be low budget operators with little overhead and low opportunity costs, these traits may be a consequence of asymmetric litigation stakes that make defendants more prepared to invest in the action than plaintiffs. In the earlier example where the defendants are exposed to a $\$ 1$ million expected loss but the plaintiffs' expected fee award is $\$ 300,000$ at most, the defendants will rationally spend more on expert witnesses, deposition preparation, discovery, and associated expenses. Given this asymmetry, a rational strategy for the plaintiff's attorney may be to compensate for it by engaging in "feigned" litigation-that is, to create and exploit a cost differential by making broad discovery requests and otherwise increasing the defendants' costs without themselves preparing for trial. Although this is the profile of the classic nuisance suit, the plaintiffs' attorneys may sometimes have no rational alternative.

Moreover, the plaintiffs' ability to create and exploit a cost differential is abetted by the defense attorneys' own interest in preparing prodigiously and billing accordingly. Hence, the plaintiffs' attorneys might subpoena crates of documents-which the defendants' attorneys zealously reviewed for privileged information and released only after costly skirmishing-although the plaintiffs' attorneys may then inspect them only cursorily. The tactics of each side would be rational: the defendants seek to increase costs reciprocally; the plaintiffs seek to preserve a cost differential. This strategy of low intensity litigation allows plaintiffs' attorneys to diversify their risks by maintaining a sizable portfolio of actions and exploiting the cost differential of each to make settlement less costly to the defendants than victory at trial.

There are, of course, limits to plaintiffs' ability to exploit a cost differential. The plaintiffs' leverage fades over the course of the litigation, because each dollar the defendants expend both reduces the future litigation expenses the plaintiffs can force upon them and pushes the plaintiffs' attorneys toward the point at which their own costs will exceed the expected fee award. Further, to have any leverage at all, plaintiffs' attorneys must pose a credible threat; this may require some past litigated victories. Thus, plaintiffs' attorneys have a strong, but not constant, incentive to invest in accumulating reputational capital. Once they have acquired this reputation, attorneys can present themselves as formi- 
dable antagonists and can exploit this capital without expending significant effort on a particular case. In effect, these plaintiffs' attorneys become "repeat players" confronting defendants who probably have not experienced major high stakes litigation and therefore may be more risk averse. In this confrontation, the inexperienced and probably risk averse defendants, faced with a potentially catastrophic loss, often can be convinced by their own attorneys to prepare an "airtight" defense. The defendants thus may be overinvesting in the action and the plaintiffs underinvesting, in each case in comparison to what fully informed and experienced clients would in the absence of agency costs. If the action becomes sufficiently protracted-which is in the mutual interest of both sides' attorneys under the lodestar formula-even risk neutral defendants may eventually recognize that settlement is less costly than continued litigation, although the odds at trial are heavily in their favor. However, if the defendants are also repeat players-such as insurance companies-they may have strategic interest in developing a reputation for toughness by fighting to a litigated victory.

What appears as a significant cost differential favoring plaintiffs may then in fact be the composite of several interrelated factors. First, plaintiffs may litigate more cheaply simply because they have to. Asymmetric litigation stakes necessitate that the plaintiffs' attorneys, as independent entrepreneurs, minimize costs, while defense attorneys can persuade their own clients to litigate according to a more luxurious style. Closely related to this first scenario is a second: defendants may exploit asymmetric stakes by increasing the ante while the plaintiffs respond by engaging in low cost, "feigned" litigation that can give the action the appearance of being frivolous. Even if defendants cannot force plaintiffs to match them dollar for dollar, they still may be able to demonstrate that protracted litigation is unprofitable for the plaintiffs because the eventual fee recovery will neither cover the plaintiffs' attorneys' opportunity costs nor compensate them for the risk associated with their contingent fee. A third possibility is that plaintiffs' attorneys can diversify their risks by managing a portfolio of individual actions; their tactics may then make sense if their hope is either to identify from among this portfolio a risk averse defendant who will settle generously or to discover a "smoking gun" that changes the litigation odds in plaintiffs' favor after only a limited search. Finally, there remains the original possibility that a litigation cost differential may sometimes enable plaintiffs' attorneys to engage in practices that resemble extortion. 
At bottom, the tradeoff between the asymmetric stakes and cost differential effects is indeterminate. To understand why, consider a case with a three to one cost differential-in which plaintiffs, by expending $\$ 50,000$ of their own time, can cause the defendants to spend $\$ 150,000$. This differential gives the case a real settlement value irrespective of the merits and illustrates the presumed effect of the cost differential. But the interplay is more complex if the plaintiffs' case has real merit. Assume, for example, that the case has a settlement value of $\$ 1$ million with an expected fee award of $\$ 200,000$. By spending over $\$ 600,000$, the defendants could force the plaintiffs' attorneys to spend time and unreimbursable expenses worth over $\$ 200,000$ - an amount that would not be completely covered by the expected fee award. This strategy is fully rational if it leads the plaintiffs to settle for, say, $\$ 250,000$. Moreover, such a strategy need seldom be pursued to the end; by beginning to spend at this rate, the defendants can signal their ability to make the action unprofitable for the plaintiffs' attorneys and thus coerce a settlement on a basis unrelated to the litigation odds. In other cases, both sides may threaten to cause the other a loss regardless of the litigation's outcome, and in this game of "chicken" we cannot confidently predict which side will break off the contest first. Even when the potential costs are much greater to the defendants, the typically smaller and underfinanced plaintiffs' attorneys may be unable to bear the risk or to finance the litigation for a protracted period.

\section{An Initial Summary}

Although the considerations discussed above are abstract and may be dwarfed by other factors in any given case, they point toward some policy objectives. Most fundamentally, if agency costs are to be reduced, the most effective monitor is likely to be the plaintiff who has the largest stake in the action. Just as the large shareholder is the most effective monitor of management in the corporate setting, the plaintiff with the largest expected individual recovery is most likely to expend time and effort in supervising the plaintiffs' attorneys. To be sure, the plaintiff with the largest expected recovery may still have an inadequate incentive to monitor, but it is possible that relatively modest expenditures by such a client could substantially reduce opportunistic behavior by plaintiffs' attorneys. For example, such a client may already have a preexisting relationship with an attorney or can benefit from an informed referral process. For this reason, other things being relatively equal, the presumption should be that the court will designate the 
attorney of the largest stakeholder as the lead counsel.

Unfortunately, other things are not necessarily equal, because the plaintiff with the largest stake in the action is often the plaintiff with the strongest desire to opt out of the class action. If we restrict this plaintiff's ability to opt out, we minimize other problems, but we may unfairly expose this plaintiff to loss. "High stakes" plaintiffs often feel that the class action subordinates their interests to those of the average class member. Part II will examine this tradeoff in greater detail, but the point of immediate relevance here is that preferring the attorneys of the largest plaintiff for the lead counsel position represents an arguably fair compromise. ${ }^{35}$ If the largest plaintiff may be locked into the action, he is also given greater control over the action in order to benefit those plaintiffs who cannot effectively represent their own interests.

Even if such a policy succeeds in reducing agency costs, it will not alone suffice to cause settlements to reflect simply the litigation odds. Other factors, including cost differentials and asymmetrical stakes, will still intrude. Ultimately, entrepreneurial litigation should be seen less as a process by which the adversaries come to agree on the litigation odds and then settle in order to avoid further transaction costs, ${ }^{36}$ and more as a variety of Nash equilibrium in which each side assumes the other is committed to an established litigation strategy. ${ }^{37}$ Typically, the plaintiffs' attorneys will assume that the defendants are committed to a dilatory strategy that maximizes the significance of the asymmetric stakes, while the defendants will believe the plaintiffs are seeking to exploit a cost differential. Acting on these beliefs, each side will follow a strategy that maximizes its position given the other's apparent intentions.

${ }^{33}$ An interesting parallel exists in bankruptcy reorganization litigation, where the Bankruptcy Act contemplates that the court will appoint as the representative of each class that member of the class who has the largest claim in principal amount. See Victor Brudney and Marvin A. Chirelstein, Cases and Materials on Corporate Finance 142-43 (2d ed. 1979). Arguably, the premise here is also that the largest claimant will be the best monitor.

so See, for example, John P. Gould, The Economics of Legal Conflicts, 2 J. Legal Stud. 279, 288-91, 296 (1973); William M. Landes, An Economic Analysis of the Courts, 14 J. L. \& Econ. 61, 66-69 (1971); Priest and Klein, $13 \mathrm{~J}$. Legal Stud. at 12-16 (cited in note 4).

37 In game theory, a Nash equilibrium refers to a stable set of strategies in a noncooperative game to which the players remain committed because each believes that no other strategy will improve his position so long as the other players persist in following their own strategies. See Martin Shubik, Game Theory in the Social Sciences: Concepts and Solutions 240-41 (1982). See also John Nash, Non-cooperative Games, 54 Annals of Mathematics 286 (1951). By analogy, one side in a class action may see the other as seeking to exploit a cost differential, while the other side sees the first as seeking to exploit its greater financial resources by pursuing a dilatory strategy; given these stable expectations about the other's strategy, each may treat the litigation odds as of only secondary importance. 
While settlements remain likely, there is little reason to believe that the equilibrium point eventually reached is necessarily determined by the action's merits. Put simply, the parties bargain less in terms of the "shadow of the law" and more in terms of each other's tactical stance. ${ }^{38}$

\section{Implementing Entrepreneurial ENForcement of LaW}

Today, private, entrepreneurial law enforcement is a fact of life that we sometimes accept and sometimes repress. Even if alternatives are possible, it is a virtual certainty that the mass tort system, as implemented by the class action, will be with us for the foreseeable future. Realism therefore dictates that we examine the ways in which it can be marginally improved. Section A below focuses on the relationship between attorney and client and addresses ways to rationalize the operation of large class actions. Section B then examines the problem of inter-plaintiff conflicts and considers alternative means of regulation by which to constrain opting out without subjecting the individual plaintiff to unfairness.

\section{A. The Uncertain Status of the Plaintiffs' Attorneys}

Early in this century, American law tacitly accepted the institution of the lawyer as an entrepreneur when it approved the use of the contingent percentage fee. A basic difference between the contingent percentage fee and two-way fee shifting (the "English rule") is that the former makes the attorney a joint venturer with the client. In contrast, under the English rule, the interests of attorney and client often can differ: the attorney may want to prosecute a weak or marginal case in order to earn a fee even when the client-who would be liable for the fees of both sides if the action were unsuccessful-would not. ${ }^{39}$

Empirical surveys of the practices under contingent fee formulas suggest that the attorney typically is the senior partner in this joint venture. ${ }^{40}$ Although most jurisdictions restrict in some way

ss The phrase "bargaining in the shadow of the law" comes from a well-known article by Mnookin and Kornhauser. See Robert H. Mnookin and Lewis Kornhauser, Bargaining in the Shadow of the Law: The Case of Divorce, 88 Yale L. J. 950 (1979).

${ }^{39}$ For a comparison of American and British attitudes toward the contingent fee, see Janet E. Findlater, The Proposed Revision of DR 5-103(B): Champerty and Class Actions, 36 Bus. Lawyer 1667, 1669-73 (1981).

to See Douglas E. Rosenthal, Lawyer and Client: Who's In Charge? (1974) (survey of practices in personal injury field concluding that attorneys typically pursued early settlements). 
the percentage that the attorney may charge,,$^{41}$ the general attitude of courts towards this system has been one of benign neglect.

This laissez-faire approach derives at least in part from the courts' desire to repress any notion of the attorney as an entrepreneur. In contrast, when courts have been forced to face this fact, their attitude has been quite different and sometimes smugly moralistic. In re Mid-Atlantic Toyota Antitrust Litigation ${ }^{42}$ is a symptomatic example. There, the plaintiffs' attorneys advised their clients (the class representatives) that they would advance all litigation costs and expenses but that ultimately the clients would be liable for those expenses in the event the action was unsuccessful or did not produce an adequate recovery. However, the attorneys in Mid-Atlantic Toyota deviated from the usual script by noting their firm's position, "as a matter of policy," not to seek reimbursement of these costs and expenses if the action was unsuccessful. ${ }^{43}$ This practice, under which the plaintiff's attorneys internalize all litigation costs, appears to be standard in antitrust litigation and was subsequently endorsed by the ABA's Kutak Commission. ${ }^{44}$ Nonetheless, because the attorneys in Mid-Atlantic Toyota committed the sin of candor by disclosing that they would not seek reimbursement, the court found that they had acquired an impermissible stake in the litigation. Based on this asserted ethical violation, the court denied class certification on the grounds that such plaintiffs could not adequately represent the class. ${ }^{45}$

An obvious criticism of Mid-Atlantic Toyota is that small clients will never willingly assume contingent liability for their attor-

11 In New York, all four departments of the Appellate Division have set forth two alternative fee schedules for determining the maximum contingent fee payable in personal injury and wrongful death actions. Schedule A permits a declining percentage, beginning with 50 percent of the first $\$ 1,000$ recovered and concluding with 25 percent of any amount over $\$ 25,000$. Schedule B permits a percentage fee not greater than one-third of the total amount received. See 22 N.Y.C.R.R. \$§ 603.7, 691.20, 806.13 and 1022.31 (McKinney Supp. 1986). Similarly, Section 474-a of the New York State Judiciary Law specifies a declining percentage schedule for medical malpractice cases that culminates by allowing only 10 percent of any amount recovered over $\$ 1,250,000$. See N.Y. Judiciary Law $\$ 474-a$ (McKinney Supp. 1986).

4293 F.R.D. 485 (D. Md. 1982).

43 Id. at 489.

44 See ABA Model Rules of Professional Conduct, Rule 1.8(e) (1983) (permitting attorney to advance expenses, the repayment of which may be contingent on the outcome of the litigation).

4s 93 F.R.D. at 488-89. But see Brame v. Ray Bills Finance Corp., 85 F.R.D. 568 (N.D.N.Y. 1979) (finding violation too "technical" to justify denial of certification); In re Agent Orange, 611 F.Supp. at 1459-60 (criticizing Mid-Alantic Toyota); In re Corn Derivatives Antitrust Litig., 748 F.2d 157, 163 (3d Cir. 1984) (Adams, concurring). 
ney's expenses. Why would any individual plaintiff with only a $\$ 1,000$ injury accept even a 10 percent risk of liability for $\$ 100,000$ in litigation expenses? Indeed, a plaintiff's willingness to accept such liability should make her an inadequate representative for the class because she would eventually have a very strong incentive to settle on any basis in order to escape this liability. If seriously applied, Mid-Atlantic Toyota's rationale would deter all but those plaintiffs having very large injuries from serving as class representatives. Although Part I suggested that such plaintiffs are probably the best representatives, they are neither generally available nor always free from other conflicts. Ultimately, the decision's logic conflicts with the law's traditional aspiration that the class action should equalize the bargaining power of small, dispersed plaintiffs against their larger, wealthier adversaries.

The immediate significance of Mid-Atlantic Toyota is limited, both because of the change in the ABA's ethical standard and because plaintiffs' attorneys could avoid the issue entirely by concealing their willingness to waive expense reimbursement. Its practical impact is largely to remind plaintiffs' attorneys that candor can be costly.

Yet, Mid-Atlantic Toyota is symptomatic of the courts' obstinate refusal to recognize the obvious truth that the plaintiffs' attorneys are the dominant partners in much class action litigation. Its logic could have a considerable future impact in the wake of the Supreme Court's decision in Marek $v$. Chesny, ${ }^{46}$ reinterpreting Rule 68 of the Federal Rules of Civil Procedure to forbid an award to a plaintiff for fees incurred after a defendant's settlement offer if the plaintiff declines the offer and then achieves a less favorable outcome at trial. Marek is clearly limited to a specified number of statutes, and its holding approved only the denial of a fee award to plaintiffs. Still, because Marek read the term "costs" in Rule 68 to include the attorney's fees authorized by 42 U.S.C. $\S 1988,{ }^{47}$ the case could logically be read to authorize the defendant in similar cases to shift its post-offer attorney's fees against the plaintiff if the trial outcome did not equal or exceed the settlement offer. ${ }^{48}$ If Rule 68 is ultimately read this broadly, the next issue will be

473 U.S. 1 (1985).

17 Civil Rights Attorney's Fees Awards Act of 1976, 42 U.S.C. § 1988 (1985). See Marek, 473 U.S. at 7-12 \& n.2. Rule 68 provides that "[i]f the judgment finally obtained by the offeree is not more favorable than the offer, the offeree must pay the costs incurred after the making of the offer." Fed. Rule of Civ. Proc. 68.

18 I doubt that Marek will be so read, and one post-Marek decision has already declined to extend it this far. See Adams v. Wolff, 110 F.R.D. 291, 293 (D. Nev. 1986). 
who-the plaintiff or his attorney-will be liable when the defendant's post-offer fees are shifted. Unless the attorney agrees to indemnify the client for these fees, the class representative is worse off than if she had contingent liability for her own attorney's expenses-which are typically smaller than the defendant's expenses. The logic of Mid-Atlantic Toyota, however, suggests that if the attorney agrees to indemnify the client, she thereby has acquired an impermissible investment in the action and hence class certification should be denied.

From a policy perspective, the choice is between truth and illusion. We could continue to pretend that the class representative is the true party in interest, or we could recognize the reality of the attorney as entrepreneur. If we insist on pretense, it will be hard to escape the reality that few plaintiffs would be willing to accept their role if they had to bear the cost of the fee shifting. ${ }^{48}$

Even permitting attorneys to indemnify clients does not by itself yield a satisfactory solution. Cost differentials and asymmetric stakes still create attorney-client conflicts. Because the plaintiff's attorney has a much smaller stake in the outcome than the defendant and because the defendant's fees typically are greater than those of the plaintiff, a settlement offer that could trigger postoffer fee shifting would give the defendant a powerful weapon. If the plaintiff's attorney has agreed to indemnify her client, she may have an overly strong incentive to settle.

The bottom line is then that asymmetric stakes make two-way fee shifting, even if limited by Rule 68's precondition of a settlement offer, an unacceptable weapon with which to arm defendants if private law enforcement is to survive. Other, less drastic alternatives are also available. For example, we could simply cancel the fee award with respect to post-offer time expended by the plaintiff's attorney. This was the actual outcome in Marek. Alternatively, if a greater incentive to settle is thought necessary, the plaintiff's attorney could be made liable for (or permitted to indemnify) expenses up to the amount of her total fee award. This latter approach still gives defendants a settlement weapon, but is at least bounded by an acceptable ceiling. Also, courts may be doctrinally more comfortable subtracting all costs, including costs that are shifted, from the attorney's fee award than in permitting the attorney to guarantee all losses.

19 The real consequence of fee shifting against the client might be to compel the plaintiff's attorney to find a client who is judgment proof. While possible in mass tort cases, this strategy may prove unworkable in securities or antitrust litigation. 
The traditional view of the attorney as a professional-a craftsman and servant, but never an independent principal-underlies not only the rule that attorneys may not invest in an action, but also two other rules that can have adverse consequences for effective private law enforcement through class actions: the rules against client solicitation and fee splitting.

Solicitation is common in entrepreneurial litigation, where the socially desirable role of the lawyer is to aggregate claims that are by themselves unmarketable. Often, clients are simply unaware that they possess actionable claims. Thus, attorneys must pursue clients, since the clients will not ordinarily come to the attorneys. The traditional prohibition on client solicitation embodied the twin fears that clients retained through unsolicited legal advice would be overcharged and underrepresented. ${ }^{50}$ These dangers are not imaginary, but the relevant question about them is: dangerous compared to what? Clients who never learn of their legal rights receive even less representation and are economically worse off. More to the point, in the context of entrepreneurial litigation, there are already alternative safeguards against the dangers of overcharging and underrepresentation. The court reviews and sets the fee award and has the power-albeit often unused-to choose the lead counsel who will administer and staff the action. Properly utilized, these powers provide a sophisticated court with adequate leverage to deal with the suspected evils in client solicitation, and they thus make a prophylactic rule against solicitation unnecessary and overbroad.

The immediate issue is not whether the rules against client solicitation need to be repealed, but whether they should be extended to the limits of their logic. Under new patterns of solicitation, plaintiffs' attorneys arrange with labor unions, social service agencies, or medical clinics to screen and refer clients to them. ${ }^{51}$ From this article's perspective, this is sensible, but from the perspective of a client control model it is offensive if the referral is motivated by the expectation of a forwarding fee or other financial benefit. Ideally, the focus for reform efforts should not be on discouraging such referrals, but on converting the referring (or at least cooperating) agency into a monitor. Here, legal ethics might play an important positive role.

The fear of referral fees also underlies the rule against fee

so See ABA Model Rules of Professional Conduct, Rule 7.3 (1983) (stressing these dangers in commentary). See also Rhode, $36 \mathrm{~J}$. Legal Educ. at 319 (cited in note 20).

${ }^{51}$ See Richards and Meier, Wall St. J. at 1 (Feb. 18, 1987) (cited in note 24). 
splitting. Subject to some exceptions, legal ethics prohibit attorneys not affliated in a firm from sharing fees from a joint representation except in proportion to the work performed by each. ${ }^{62}$ This rule does not apply, however, to fee sharing within a law firm, where a variety of factors other than the work performed affect the allocation of the firm's income among its partners. ${ }^{53}$ From an economic perspective, it is self-evident that some partners contribute labor and services, while others supply capital, reputation, or client contacts that are equally valuable. If so, why should attorneys not affiliated in the same firm be denied a similar ability? More specifically, why should legal ethics prohibit one group of attorneys from occupying creditor or investor relationships with respect to another group of attorneys who actually handle the litigation of a class action? From an efficiency perspective, such a relationship promises mutual gains from exchange. Both groups thereby can diversify their portfolios, and the creditor attorneys could, in theory, lend at lower cost because they, as fellow specialists, can monitor their debtors more effectively and at lower cost. ${ }^{54}$

Although the issue has never arisen in this stark and simple a fashion, it was implicated in the Agent Orange litigation. ${ }^{55}$ There, the team of plaintiffs' attorneys who had initiated the action had run out of funds and were stalled well short of trial. After brief negotiations, a new group of attorneys assumed control of the plaintiffs' steering committee in return for their commitment to contribute up to $\$ 250,000$ each in litigation expenses. ${ }^{56}$ In payment for this commitment, the original plaintiffs' team agreed that they

${ }^{62}$ See ABA Model Rule 1.5(e) (1983). Under this rule, attorneys who are not affiliated in the same firm may divide fees in a manner not "in proportion to the services performed by each lawyer" only with "the written permission consent of the client." Id. In the case of a class action, it is typically impossible to obtain the consent of each client, although presumably the court can consent for them. This, however, intrudes the court into a private ordering process.

${ }^{53}$ For a discussion of law firm profit sharing arrangements, see Ronald J. Gilson and Robert H. Mnookin, Sharing Among the Human Capitalists: An Economic Inquiry into the Corporate Law Firm and How Partners Split Profits, 37 Stan. L. Rev. 313 (1985).

st Of course, such a relationship, if extended over time, could amount to a "firm" and thereby outflank the prohibition on fee sharing. Also, some courts have recognized that the plaintiffs' steering committee can amount to an "ad hoc law firm." See note 58 and accompanying text.

ss See In re Agent Orange, 611 F.Supp. at 1452, 1454-55, 1458-62, rev'd, 818 F.2d 216 (2d Cir. 1987). For further discussion of the fee sharing arrangement in this case, see $W$. John Moore, Fee-Splitting Agreement Draws Attention of Agent Orange Judge. Legal Times 1, col. 2 (Nov. 5, 1984). See also Unfaithful Champion at 57-64 (cited in note 1).

s8 The incoming attorneys ultimately contributed almost $\$ 1.5$ million to finance the litigation. See In re Agent Orange, 611 F.Supp. at 1454-55. See also Schuck, Agent Orange at 121 (cited in note 19). 
would turn over any fees awarded to them to the incoming attorneys until the latter had received a specified return on the expenses they had advanced. ${ }^{57}$ In substance, this fee-sharing agreement resembled a pledge of an expected fee award, and it held out to the incoming attorneys the expectation of a 300 percent return on their investment if the action were successful. Once the action was settled, however, some of the original attorneys found that this agreement would compel them to transfer virtually all the fees the court awarded to them. Seeking to renege on their agreement, these attorneys asked the court to invalidate the fee sharing agreement, primarily on the ground that it violated ethical rules prohibiting fee splitting. Judge Weinstein neatly sidestepped the rules against fee splitting by finding that the plaintiffs' attorneys constituted an "ad hoc law firm" and thus could allocate fees without violating the rule. ${ }^{58}$

On appeal, the Second Circuit reversed and invalidated the fee distribution on the ground that it created a conflict of interest with the class and might encourage premature settlements. ${ }^{58}$ The logic of this position seems perversely flawed, because the actual incentives are, if anything, the reverse: a 300 percent rate of return could induce the "investor" attorneys to expend unnecessary amounts and delay the action's settlement to do so. While Judge Weinstein found that this had not happened and that all expenditures were reasonable, the revealing fact is that the Second Circuit panel misunderstood the incentiives. What it did understand, however, is that it did not like the concept of "investor attorneys" and was accordingly unwilling to accept the legitimacy of "ad hoc" plaintiffs' firms within which fees could be shared.

When, if ever, should courts invalidate fee-sharing arrangements within the "ad hoc" plaintiffs' law firm? Although the law generally does not regulate contracts between consenting adults, it is possible to hypothesize particular contractual arrangements among the attorneys that (although not present in Agent Orange)

${ }^{87}$ See In re Agent Orange, 611 F.Supp. at 1454-55.

ss Id. at 1458-59 (emphasis removed). Judge Weinstein also required advance approval of such agreements by the court in all future cases. Id. at 1455-57, 1462-64. Such a rule does seem salutary in order to preclude very different kinds of agreements that might in fact produce premature settlements. See note 60 .

69 In re Agent Orange Product Liability Litigation, 818 F.2d 216 (2d Cir. 1987). Judge Minor's opinion seems to have accepted the usury argument as well, because it emphasizes that some "investor" attorneys received up to a twelvefold increase in fees under the agreement. 
could adversely affect the interests of the clients in other cases. ${ }^{60}$ Still, fee-splitting agreements that seem outrageous to a reviewing court may have strong efficiency justifications. Consider, for example, a case where an incoming team of attorneys demands that the former plaintiffs' team transfer 90 percent of any fee award they receive from the court to the incoming attorneys in return for their agreement to finance the action through trial. This is not necessarily an example of overreaching or usury (as the original attorneys in Agent Orange claimed). Instead, the agreement could reflect the incoming team's judgment that the work done by the prior team was valueless. Perhaps the original attorneys misunderstood the case or pursued a hopeless legal theory. In any event, the incoming team may believe they will have to start virtually from scratch. Alternatively, the incoming team may see the action as an extreme long shot, which they will invest in only if the prior plaintiffs' team will subordinate their expected return. Because any fee award to the initial team is likely to reduce the fee award to the successor team, it is sensible for the latter group to want a subordination agreement. That is, if there is an upper boundary on the total compensation that the court is willing to award to all the plaintiffs' attorneys, any award to the original team implies a potential loss to the new team. ${ }^{61}$ Thus, if a court interferes with the plaintiffs' attorneys' internal arrangements, it may deprive the action of necessary capital.

A final reason for a rule of judicial benign neglect is that the original plaintiffs' team will have a deep and active market in which to search for new partners who can supply capital to their "ad hoc law firm."62 Given natural incentives to find the cheapest supplier, there seems little need for this form of judicial rate of

${ }^{60}$ For example, if the incoming attorney agreed to bear the future costs of a litigation already well advanced in return for 50 percent of any fees awarded to the other attorneys, such an individual would have a strong incentive to settle prematurely in order to minimize his costs. Unfaithful Champion at 62-63 (cited in note 1). See also In re Agent Orange, 611 F.Supp. at 1460-61 (discussing this incentive problem). Although such examples can be postulated, they are unlikely to arise because the parties to the fee sharing agreement will seldom negotiate an arrangement with such obviously perverse incentives. At most, such a danger would seem to justify disclosure of the agreement to the court for its consideration.

61 This conclusion assumes that the total fee award will continue to fall in the historically prevailing range of 20 to 30 percent. See note 31 .

${ }^{62}$ The size of the American bar has almost doubled over the last decade, growing from 396,000 licensed lawyers to an estimated 675,000 in 1985 . City of Riverside v. Rivera, 106 S.Ct. 2686, 2701 n.4 (1986) (Powell, concurring). Meanwhile the overall population has grown at a much more modest rate. This suggests that within the private market for legal services, supply is growing faster than demand (assuming that demand remains a relatively constant percentage of total population). 
return regulation. Ultimately, both Mid-Atlantic Toyota and Agent Orange evidence the difficulty that courts have with the simple truth that litigation is costly. In fact, litigation is too costly for the small client. While judicial regulation may be justified to protect the client from unfair arrangements, it is far less justified to protect the attorney from agreements he voluntarily entered. Yet, it is the attorney, not the client, who gains protection from cases like Agent Orange, and over the long run the cost of this paternalism may be borne by the client.

\section{B. The Problem of Inter-Plaintiff Competition}

Class actions represent a form of collective action and thus are subject to the problems that often confound attempts at such action. This section will focus in particular on two such problems: (1) adverse selection and (2) the common pool problem. Together, these problems may give the "high stakes" plaintiff an incentive to opt out from the class action -an incentive that is independent of the self-interested plaintiff's attorney's own incentives. Thus, restricting the plaintiff's right to opt out as a remedy for attorney opportunism may prove counterproductive to the client's own interests.

At the outset, it is useful to divide class actions into three categories:

- Type A class actions are those in which each claim would be independently marketable even in the absence of the class action device. By "marketable" I mean either that the client could convince an attorney to take the case on a contingent fee basis or that the client would herself pay the attorney on some other basis. In Type A actions, client control is possible, and opting out need only be a residual protection if the client feels the action is being pursued or settled in a manner that is adverse to her interests. From the client's perspective, it is often rational to prefer the class action form with respect to marketable claims because (1) it economizes on transaction costs or permits greater financial or other resources to be assembled to counteract the typically greater resources of the defendants, (2) it threatens risk averse defendants with greater liability and so deters them from going to trial, and (3) it avoids a "race to judgment" among competing plaintiffs who fear either the impact of precedents in other related cases or that defendants' assets may be insufficient to fund the aggregate recoveries. Of these reasons, the most important is likely to be the last: namely, the desire to 
minimize inter-plaintiff competition for the defendants' limited assets and any award of punitive damages. ${ }^{63}$ As a practical matter, "high stakes" plaintiffs are more likely to be risk averse than plaintiffs who expect smaller recoveries; for "high stakes" plaintiffs, it is thus preferable to share the recovery rather than to take a gamble on competing against each other in a zero-sum game over a limited fund.

Because client monitoring of attorneys is economically feasible in Type A actions, opting out becomes less justifiable on a policy level. Arguably, some special justification (such as a policy dispute or the logistical problems of a distant forum) should be present before it is allowed, because in such a context the decision to opt out may be more in the attorney's interests than the client's. Still, the practical relevance of this point is limited by the difficulty of distinguishing Type A actions from the next two categories.

- Type B class actions are those in which no claim would be independently marketable. " "Opting out" is by definition infeasible. Here, client control is illusory; probably, few clients have a large enough stake to justify monitoring the attorneys. The risk of attorney opportunism is substantial, although "fluid recoveries" and non-pecuniary settlements may mask such opportunism.

- Type $C$ class actions are those in which there are both marketable and unmarketable claims. Whether the average claim value is high (as in the Type A class action) or low (as in Type B actions), the distinctive fact about Type $\mathrm{C}$ class actions is that a high variance characterizes the settlement values of the total

o3 This possibility of a limited fund places the plaintiffs in a position much like that of depositors in an uninsured bank who have heard a rumor that the bank is insolvent. AIthough they recognize that the rumor may be false, they also know that a "run" on the bank could cause its insolvency and hence it may be unwise not to join the run. Rational individuals are thus compelled to act in a manner that is irrational from a collective standpoint. The answer to this problem is, of course, to require collective action and preclude the "race to judgment." This is the basic and sensible rationale for the mandatory class action under Rule 23(b)(1).

of There are some class actions in which it is very clear that no individual plaintiff would have sued. See, e.g., In re Cuisinart Food Processor Antitrust Litig., 1983-2 Trade Cases (CCH) I 65,680 at 69,467 (D. Conn.) (damages before trebling ranged from $\$ 32$ to $\$ 75$ per class member; relief gave transferable coupons to approximately 1.5 million purchasers); Ohio Public Interest Campaign v. Fisher Foods, 546 F.Supp. 1 (N.D. Ohio 1982) (\$20 million in food coupons distributed to residents of Northeast Ohio counties); Colson, 59 F.R.D. 324 (cited in note 15) (future guests at Hilton hotels to receive a discount of fifty cents a day). For other cases, see Jules Coleman and Charles Silver, Justice in Settlements, 4 Social Phil. \& Policy 102, 138 (Autumn 1986). 
portfolio of the claims aggregated within the class action. With this variance come conflicts among the members of the plaintiff class that are independent of agency costs and attorney disloyalty (although that factor may exacerbate the tension) and that reveal the deeper problems with proposals for "bureaucratic justice."

1. Large class actions and the problem of adverse selection. Although Type B suits correspond most closely to the traditional rationale for class actions, ${ }^{65}$ Type $\mathrm{C}$ actions are probably much more common, particularly in the mass tort context, because the class action invites the plaintiff with a legally weak claim to join it.

Consider the position of a plaintiff whose claim faces either serious problems of factual proof or legal adequacy or who has suffered relatively minor damages. Rationally, such a plaintiff should gravitate to the class action because she has no alternative. In economic terms, this is an instance of "adverse selection." At bottom, adverse selection involves a problem of hidden information-one party to a contract knows something that the other does not. ${ }^{66}$ The phenomenon is probably best known in the context of insurance markets, where insurers have long recognized that the population purchasing insurance against any risk will have a disproportionately large number of high risk individuals. Similarly, the "hidden information" in the class action context involves either a legal or factual weakness in a plaintiff's case. In effect, this plaintiff seeks to submerge herself within the larger class and thereby escape the potentially fatal deficiencies in her individual case. Many of the plaintiffs in Agent Orange and similar cases claimed to suffer from a variety of illnesses that could not be linked scientifically to exposure to the toxic substance at issue. ${ }^{67}$ Alternatively, their very real illnesses-cancer, leukemia, heart disease-may have had independent origins. Others had illnesses that fit within the known medical etiology, but they could not show prolonged exposure to the toxic substance, or they worked in other occupations also known to have

Bs That class actions enable victims to vindicate rights that would otherwise be illusory provides the most widely accepted justification for the class action. In Phillips Petroleum v. Shutts, 472 U.S. 797 (1985), where the average claim was for $\$ 100$, Justice Rehnquist noted that "most of the plaintiffs would have no realistic day in court if a class action were not available." Id. at 809 .

${ }^{B 6}$ See Kenneth Arrow, The Economics of Agency, in John Pratt and Richard Zeckhauser, eds., Principals and Agents: The Structure of Business 37, 38-40 (1985); Michael Rothschild and Joseph Stiglitz, Equilibrium in Competitive Insurance Markets: An Essay on the Economics of Information, 90 Quart. J. Econ. 629 (1976).

${ }_{67}$ See Epstein, $13 \mathrm{~J}$. Legal Stud. at $479-80$ (cited in note 6). 
cause the disease. Still others may have sustained injuries whose causal connection to the exposure was relatively clear but whose economic value might not have justified the litigation. The logical result here is a Gresham's Law effect: "bad" plaintiffs drive out the "good." Bs Because those with weak cases may reduce the average recovery, those with stronger than average claims may wish to flee the class action.

The impact of adverse selection is likely to be particularly pronounced in the mass tort context. There, the variance in claim values-in terms of injury severity and legal merit-will be substantial and the number of plaintiffs is large enough to make the marginal contribution of a high stakes plaintiff to the action's overall settlement value relatively insignificant. By contrast, in a smaller action all plaintiffs will wish to keep a severely injured victim in the action both to enhance its overall settlement value and to serve as a vivid illustration for the jury.

The significance to the adverse selection problem by itself is open to reasonable debate, because "small stakes" plaintiffs will in most cases never learn of the pendency of the class action and thus will not join in it. However, as next will be seen, the problem of adverse selection dovetails with, and is exacerbated by, the competition among plaintiffs' attorneys for control of the class action.

2. The common pool problem. A large class action may involve one hundred or more plaintiffs' attorneys. ${ }^{69}$ Either individually or in small groups, they may have filed class or individual actions in various district courts across the nation, often piggybacking on an earlier action brought by public authorities that signaled the existence of a potentially valuable cause of action. These actions then are consolidated in a single district court by the Judicial Panel on Multidistrict Litigation, technically for pretrial proceedings, but typically for trial as well. ${ }^{70}$ The result is an unstable caucus of attorneys that is expected to function as an "ad hoc law firm."

Until recently, the Manual on Complex Litigation instructed the trial court to let the plaintiffs' attorneys elect their own lead

os "Gresham's Law" is arguably another example of adverse selection at work: when two kinds of money are in use, one that has a value outside its use as currency (like gold) and one which does not (like paper dollar bills), the "bad" money (paper currency) drives the "good" (gold) out of circulation. George Akerlof's application of this principle to the used car market is a classic of modern economics. George A. Akerlof, The Market for "Lemons": Quality Uncertainty and the Market Mechanism, 84 Quart. J. Econ. 488 (1970).

6 See Private Attorney General at 223 n.17 (cited in note 1).

${ }^{70}$ See 28 U.S.C. $\S 1407$ (a) (1982). See also note 5. 
counsel. ${ }^{71}$ The result was the legal equivalent of an unsupervised political convention without procedural rules or even a credentials committee. Rival slates would form. Competing groups would invite other attorneys into the action in order to secure their vote for lead counsel. Eventually, a political compromise would emerge. ${ }^{72}$ The price of such a compromise was often both overstaffing and an acceptance of the free-riding or marginally competent attorney, whose vote gave him leverage that his ability did not.

Less obvious-but potentially more important-is the corrosive impact of this system on the plaintiff's attorney's willingness to search for actionable violations: the attorney who discovers a new cause of action may have to share the expected reward with the other attorneys who later file parallel class actions that the court eventually consolidates into a single nationwide proceeding. Given the ambiguities in the law and the substantial discretion accorded the court, the issue of who will control the action and thus claim the greater share of the fee award is simply too uncertain in many cases to justify investment in search costs. As a consequence, the private attorney general today operates largely by piggybacking on the earlier efforts of governmental enforcers. The leading exceptions to this generalization are mass disaster and products liability cases, since the attorney need not incur extensive search costs where the event has been widely publicized or the client is already aware of the injury.

On a more abstract level, the pattern described above represents an example of a "common pool" problem. ${ }^{73}$ Such problems

" See Manual for Complex Litigation $\S 1.92$ (5th ed. 1981). More recently, the Manual has been changed to give the judge authority to select counsel. See Manual for Complex Litigation Second $\$ 20.224$ (1985). However, the court is still advised "to give special consideration to the suggestions of counsel" in determining an attorney's role in a class action. Id.

72 For examination of this process, see Private Attorney General at 248-61 (cited in note 1), discussing In re Fine Paper Antitrust Litigation, 98 F.R.D. 48 (E.D. Pa. 1983), aff'd in part, rev'd in part, 751 F.2d 562 (3d Cir. 1984).

${ }^{73}$ For a standard discussion of this problem, see Richard James Sweeney, Robert D. Tollison, and Thomas D. Willett, Market Failure, The Common-Pool Problem, and Ocean Resource Exploitation, 17 J. L. \& Econ. 179 (1974). The term "common pool problem" derives from the oil and gas industry, where individuals who owned drilling rights that tapped into a common body of oil or gas competed with each other to withdraw the resource at the fastest possible rate, even though the value of the resource could have been maximized by a different strategy. The standard solution to a "common pool" problem in the oil and gas industry has been compulsory unitization, and the mandatory class action is a functional analogue to this strategy.

Common pool problems can also result in underutilization of a resource: for example, a newly discovered gold field in which no prospector can protect his claim and thus in which little long-term investment is made. Similarly, the prospect of battles for control of a class action reduces the incentive to invest in search costs. 
arise whenever there is difficulty in identifying or asserting property rights over an asset. Here, the asset is the expected fee award. The standard solution to this problem is to allocate the property right in question so as to establish clear and enforceable entitlements. However, the economically efficient solution is an unpromising prescription for class actions. As I have noted elsewhere, efforts to allocate ownership rights in an action among competing attorneys or firms-whether pursuant to an auction or judicial fiat-will encounter substantial obstacles. ${ }^{74}$ Still, even if a feasible ex ante solution seems likely to escape us for some time to come, courts can mitigate the problem ex post by allocating control of the large class action at an early stage in the litigation and by favoring the attorney or firm that principally incurred the search costs that led to the action's filing.

Today, inter-plaintiff competition over control of litigation takes two basic forms. First, there is the usual struggle over the selection of lead counsel and the membership of the steering committee that manages the action. Some jockeying for position by plaintiffs' attorneys is probably inevitable and may even enhance the court's ability to choose. Nonetheless, the policy objective should be to encourage greater hierarchical control within the ad hoc "firm" so that the lead counsel, once selected, does not have to negotiate continuously with various constituencies, or to award them patronage in return for their votes, in order to remain in power. Once freed of "political" constraints, the plaintiffs' lead counsel could prune deadwood from the "ad hoc firm" but could also invite in other attorneys and firms in order to achieve efficient risk-sharing. From a distance, it is difficult to distinguish overstaffing from sensible portfolio diversification that allows plaintiffs' attorneys to participate on a high risk venture, and it is precisely this difficulty that points up the superiority of private ordering, as modified by a market-mimicking strategy, over a more heavyhanded approach of bureaucratic regulation.

The second form of inter-plaintiff competition involves "opting out." Today, losers in the struggle for lead counsel designation commonly pursue their claims separately, because they can usually anticipate being excluded from a profitable role in the action if they are not named to the steering committee. Alternatively, plaintiff's attorneys may oppose class certification or file a state action before certification is granted. The result is to produce multi-for-

74 See Unfaithful Champion at 77-79 (cited in note 1). 
um litigation with consequences that are next described.

3. The rush to judgment. Although competition is usually beneficial to society, some forms of competition among plaintiffs' attorneys can result in unnecessary costs, both to the parties and to the public. These "deadweight losses" chiefly result because separate actions induce a rush to judgment. Plaintiffs in the various individual actions may have to fear the potentially preclusive or otherwise damaging effect of a judgment or settlement in the class action. Similarly, punitive damages may be denied subsequent litigants if they have been awarded in an earlier proceeding. ${ }^{75}$ Defendants may exploit inter-plaintiff competition both by bringing the weaker individual cases to trial ahead of the class action in order to create unfavorable precedents and by playing rival state and federal classes off each other in order to gain settlement leverage. ${ }^{76}$ Opting out, if it occurs on a sufficiently large scale, may also complicate the settlement of the class action (because it denies the defendants the ability to know their total liability at the time of settlement) and, if the defendants assets are insufficient, may produce a battle over the distribution of those assets. ${ }^{77}$

Under current law, a state action cannot be consolidated by the Federal Multidistrict Judicial Panel unless the defendants remove the action to federal court. In response, numerous commentators have properly decried the lack of coordination between state and federal courts and among various state courts. ${ }^{78}$ Yet even if intelligent and well-meaning judges at state and federal levels could confer, the fundamental problems of incentives and competition would remain. Although federal courts may try to limit the proliferation of parallel actions by enjoining plaintiffs from bringing suit in state court or by staying state discovery proceedings, the Anti-Injunction Act denies federal courts the power to stay preexisting state actions. ${ }^{78}$ As a result, even if a diligent federal

7s See notes 85-86 and accompanying text.

${ }^{76}$ See Note, 96 Harv. L. Rev. at 1148 (cited in note 7).

77 If there is a "limited fund" out of which the recovery may be satisfied, the Advisory Committee's Note to Fed. Rule Civ. Proc. 23 specifically notes that certification of a Rule 23(b)(1) "mandatory" class action-from which the plaintiffs may not opt out-is justified. See Proposed Rules of Civil Procedure, 39 F.R.D. 69, 101 (1966); Note, 96 Harv. L. Rev. at 1157-58 (cited in note 7). A significant disagreement exists, however, as to how certain the court must be in advance that the fund will be limited. Compare In re Agent Orange Product Liability Litigation, 100 F.R.D. 718, 725 (E.D.N.Y. 1983), and In re Dalkon Shield, 693 F.2d 847, 851 (9th Cir. 1982).

${ }^{78}$ See, e.g., Weinstein, 11 Colum. J. Envtl. L. at 23-25 (cited in note 7).

79 Courts have viewed the Anti-Injunction Act, 28 U.S.C. $\$ 2283$ (1982), as barring a stay of state actions already filed. For an application of the Act to class certification, see In 
court were able to stretch its powers under Rule 23(b)(1) to enjoin parallel actions quickly once it certified a mandatory class action, reasonably intelligent plaintiffs' attorneys could anticipate this move, and their ex ante response should be to commence a state action at or before the filing of their federal action, thereby securing a fallback position in the event they are excluded from control positions on the plaintiff's team.

Economic incentives drive these strategies. If a plaintiff's attorney accepts a minor role on the plaintiff's litigation team, she probably will not receive any significant fee multiplier, and further, her ability to undertake billable work will be subject to the lead counsel's control over work assignments. Although centralized control of the plaintiff's team may promote good management, it also promotes opting out by the inevitable losers in the struggle for control of the action. If the predictable losers in the political struggle opt out and maintain independent actions in federal court, these "tag along" actions will almost certainly be consolidated with the class action. Although the position of these attorneys on the litigation team will probably remain a subordinate one, ${ }^{80}$ they are now free to enter into a contingent fee agreement with their clients under which they may receive 30 percent or more of any recovery awarded. In short, it may be highly profitable for the attorney-but not necessarily for the client-to become a free rider on the efforts of the plaintiffs' team in the class action. ${ }^{81}$ If a non-lead

re Federal Skywalk Cases, 680 F.2d 1175, 1180-84 (8th Cir. 1982). But see Note, 96 Harv. L. Rev. at 1159 n. 69 (cited in note 7). Because the Anti-Injunction Act permits a stay of state court proceedings when necessary in aid of the federal court's jurisdiction, the rival riew is that the federal court could enjoin preexisting state actions in the case of a Rule 23(b)(1) class action. See Weinstein, 11 Colum. J. Envtl. L. at 23 n.61 (cited in note 7). See also In re Baldwin-United Corp. Litigation, 770 F.2d 328, 336 (2d Cir. 1985).

${ }^{8}$ Paradoxically, under circumstances that are likely to recur with increasing frequency, the plaintiff's attorney may increase her chance to participate in the control of the action by opting out. This is because some courts have recently begun to appoint plaintiffs' steering committees composed of both attorneys in the class action and attorneys who opt out and file individual "tag along" actions that are consolidated with the class action. Such a joint class and individual action steering committee permits greater coordination, may encourage cost sharing, and makes obvious sense, but it does give rise to a strange incentive: the attorney denied a seat on the plaintiffs' committee may opt out and hope to gain one of the committee seats allocated to those handling the individual actions.

s1 Although the attorney is better off, the client may be worse off: not only will the client pay 30 percent or more to her own attorney, but she also may have some liability for a portion of the legal fees payable to the attorneys for the class, even though she has opted out and secured private counsel. See In re Agent Orange, 611 F.Supp. at 1315-17; Vincent v. Hughes Air West, Inc., 557 F.2d 759, 771-72 (9th Cir. 1977). Various sensible solutions can be suggested to this problem; for example, an "inactive" counsel could be required to contribute to the class fund from her own fee receipts. See In re Air Crash Disaster at Florida 
attorney opts out to pursue an independent state action, the attorney may also escape the ability of a federal court judge to compel opting-out plaintiffs to share costs with the class plaintiffs. ${ }^{82}$

Separate actions do not, however, necessarily disserve clients and benefit only their attorneys. For example, an attorney may wish to pursue a state action in the belief that she can obtain a jury trial more quickly or secure higher damages. Typically, she knows that the federal judge handling the consolidated actions will be well aware of the limited solvency of the defendants and that the judge might therefore seek some equitable damage allocation formula. In such a case, the district court will likely resist the individual plaintiff's claim that her damages were disproportionately severe. Yet in an individual action at the state level, the good trial lawyer may believe she can shock a jury into awarding severe damages in order "to send a message" to similar defendants. But while such a state action may thus serve the interests of both attorney and client, such proceedings multiply the judicial costs and impede overall settlement.

A further dimension to inter-plaintiff conflict involves the specialization of attorneys. In a series of recent products liability and mass disaster cases, low visibility battles have arisen between attorneys with substantial experience in federal class action practice and old time "trial lawyers" whose major experience has been in state court personal injury work. ${ }^{83}$ The latter group has repeatedly resisted class certification or sought to opt out, while the former has sought to have courts certify a mandatory class action.

This conflict first erupted into public view in the wake of the 1981 collapse of the Hyatt Regency Skywalk in Kansas City, Missouri, which killed 114 persons and injured 269 others. ${ }^{84}$ This inci-

Everglades, 549 F.2d 1006, 1019-21 (5th Cir. 1977); Doherty v. Bress, 262 F.2d 20, 22 (D.C. Cir. 1958). See also notes $123-27$ and accompanying text.

${ }_{82}$ See In re Agent Orange, 611 F.Supp. at 1317 (noting power of federal court to require counsel for individual plaintiffs in multidistrict cases to contribute a portion of their fees to the class to defray its discovery costs where the individual plaintiffs made use of these discovery materials). See also Doherty, $262 \mathrm{~F} .2 \mathrm{~d}$ at 22 (cited in note 81 ). This power seems to have been utilized, however, only with respect to actions consolidated before the court, and thus both the plaintiff and the attorney in a related proceeding in state court are likely to be immune.

${ }^{83}$ See sources cited in note 9. Underlying this conflict may be the tendency for each side to try to protect its sunk investment in human capital. The "old time" trial lawyers are at a particular disadvantage in complex litigation, where the key issues involve class certification and related motions and where trial is less likely given the enormous liabilities at stake. Conversely, federal procedure experts may have far less expertise in trial techniques, which may be the decisive tactical consideration in state court.

${ }^{84}$ For a good discussion of the facts, see Stewart, Wall St. J. at 1 (cited in note 16). See 
dent provoked a host of actions, all initially filed in state court. Then came the surprise. Another group of attorneys filed a federal class action and sought to have all the pending cases transferred to federal court. They secured a well-known attorney from a respected Washington, D.C. firm to serve as lead counsel, knowing that local counsel in the state actions could not match his prestige. This development threatened to divest the state court attorneys of pending actions in which they typically had a one-third contingency and to substitute an action in which they would be, at best, second class participants. Although the attorneys in the state actions were ultimately successful in resisting mandatory certification, the federal court action substantially reduced their recoveries. Because the federal class action sought punitive damages, the defendants sought to use the pendency of the federal action as a basis for denying punitive damages in the state actions. ${ }^{85}$ If punitive damages can only be awarded in one action, the obvious result is the familiar rush to judgment between those running the state and federal actions. Exploiting this factor, the defendants were able to induce virtually all of the state court plaintiffs to settle on the eve of the federal trial for compensatory damages and total punitive damages of $\$ 20$ million. ${ }^{88}$ Afterwards, the defendants reached a similar settlement with the federal court plaintiffs (who ultimately consisted only of twenty-four individuals who did not opt out), except that this second settlement was sweetened by the defendants' agreement to pay up to $\$ 3.5$ million in attorney's fees. According to neutral observers, these settlements came cheaply; the lone state plaintiff who actually went to trial won a jury verdict of $\$ 15$ million, reduced to $\$ 12.75$ million on appeal. ${ }^{87}$

The Hyatt Skywalk story has now been repeated in several other cases involving the same basic conflict between federal specialists and old time trial lawyers. ${ }^{88}$ What lessons are to be learned from it? First, the Hyatt Skywalk case is a clear example of a

also In re Federal Skywalk Cases, 680 F.2d 1175, 1177-80. Commentators have cited this case as an example of poor federal-state coordination. See, for example, Weinstein, 11 Colum. J. Envtl. L. at 25 (cited in note 7); Comment, Federal Mass Tort Class Actions: A Step Toward Equity and Efficiency, 47 Albany L. Rev. 1180, 1185-86 \& n.28 (1983).

ss See In re Federal Skywalk Cases, 93 F.R.D. 415, 425 (W.D. Mo. 1982) (questioning whether Missouri law would permit multiple punitive damage awards), vacated, 680 F.2d 1175 (8th Cir. 1982). See also Note, 96 Harv. L. Rev. at 1145-46 \& n.7 (cited in note 7).

${ }_{86}$ See Stewart, Wall St. J. at 12, col. 3 (cited in note 16) (noting that defense attorneys "warned" state court plaintiffs' attorneys that they would lose claim to punitive damages if they did not settle before federal trial).

s7 Id.

see sources cited in note 9 . 
Type A action; all the plaintiffs had marketable claims. In these actions, the incentives to join together in a class action are relatively weak (as shown by the fact that most plaintiffs opted out in Hyatt Skywalk). However, it also seems that when the plaintiffs divide, they are conquered. Whether the rush to settle is motivated by fear of preclusive effect or by knowledge that punitive damages are likely to be awarded in only one action, the consequence is the same: the defendant's liability is reduced. Second, significant disparities among plaintiffs are inevitable. In the Hyatt Skywalk case, virtually uninjured plaintiffs received sums well in excess of that received by the families of decedents. ${ }^{89}$ Third, simultaneous litigation of the same action in different courts is socially wasteful.

Despite these lessons, this pattern is likely to persist. Old time trial attorneys are severely disadvantaged in the organization of a class action because complex federal litigation is not their speciality. Thus, they will continue to resist certification or try to opt out. The conflict is, in this light, between two factions with different kinds of specialized human capital, and neither faction-the federal practitioner or the old time trial lawyer-is at home on the other's turf. Moreover, if parallel individual actions can be filed before the federal class action, precluding opting out might even intensify the race to judgment, since state court plaintiffs would then have to fear the potentially preclusive effect of a federal judgment. Hence, their incentive to settle early would be even stronger.

One answer might be legislation authorizing federal courts to consolidate all actions involving the same subject matter as a case pending before it. ${ }^{90}$ Although such a removal statute merits serious consideration, there are predictable objections. First, federal removal of state tort actions may derogate important principles of federalism. ${ }^{\text {i1 }}$ In Hyatt Skywalk, for example, this solution would mean that an individual injured in the state of Missouri could not use the Missouri state court system to adjudicate a simple tort claim if a federal court action had been brought elsewhere. In addition, Hyatt Skywalk is a deceptively simple case in that there was

s8 See Stewart, Wall St. J. at 1 (cited in note 16) (noting that lead plaintiff, who claimed only that "her legs were scratched while she was walking out of the hotel" received $\$ 172,500$ ). Such a plaintiff seems to illustrate the problem of adverse selection, discussed above in text at notes $65-69$.

so For a related proposal limited to mass disaster cases, see Weinstein, 11 Colum. J. Envtl. L. at 44-47 (cited in note 7). Judge Weinstein also proposes authorizing the Judicial Panel on Multidistrict Litigation to switch cases between state and federal courts. Id. at 47.

21 For a recent discussion of these values, see Andrei Rapaczyniski, From Sovereignty to Process: The Jurisprudence of Federalism After Garcia, 1985 S.Ct. Rev. 341. 
a single tortious act clearly bounded in time and space. In most products liability cases, the situation is far more complex. If, for example, a California plaintiff were compelled to litigate in New York because New York was the forum in which the federal class action was being heard, the burden on the plaintiff would be considerable. The burden on a distant litigant may compel a limited constitutional right to opt out. ${ }^{22}$

Second, old-time trial lawyers may be right to claim that state courts are more favorable to plaintiffs and grant higher recoveries. This suggests that the class action forum actually may favor those whose injuries or legal claims are weaker at the expense of those whose injuries or claims are stronger. This possibility requires us to reconsider the problem of adverse selection and merits a separate examination below.

4. The case for and against opting out. Plaintiffs flee the class action for essentially two reasons-one good, one bad. The . "bad" reason is that their attorneys are able to earn greater compensation in individual actions. The "good" reason is that the client may be better off in an individual action, particularly one in a state court before a jury. Indeed, some empirical research supports the conventional wisdom that other things being equal, plaintiffs are likely to receive a higher recovery in an individual action than in a class action. ${ }^{\text {3 }}$

Several reasons explain why plaintiffs who opt out are likely to - do better. First, those who favor the use of mandatory class actions under Rule 23(b)(1) maintain that the plaintiff who opts out is attempting to usurp a limited fund and reap a windfall recovery that will reduce the awards to other plaintiffs. ${ }^{94}$ In this view, class action litigation is a zero-sum game in which various plaintiffs compete to obtain a recovery from a defendant with insufficient assets. To the extent that plaintiffs are risk averse, they would prefer a more certain but lower recovery to the prospect of a higher ex-

92 See text accompanying note 103.

${ }^{93}$ A study by the Rand Institute for Civil Justice found that as each additional coplaintiff was added in civil actions in Cook County, Illinois, the original plaintiff could expect to receive 27 percent less compensation. See Audrey Chin and Mark A. Peterson, Deep Pockets, Empty Pockets: Who Wins in Cook County Jury Trials 48 (Rand Report No. R3249-ICJ) (1985).

94 See, e.g., In re Agent Orange, 100 F.R.D. at 725. At present, courts are divided between those that require the proponents of class certification to show the existence of a limited fund that will "inescapably" affect the plaintiff's claim, see In re Dalkon Shield, 693 F.2d at 851-52, and those that require only that a "substantial probability" be shown, see In re Agent Orange, 100 F.R.D. at 726. See also Note, 96 Harv. L. Rev. at 1145-46 (cited in note 7). 
pected value subject to the risk that the defendants' assets would not cover the aggregate of the individual judgments. ${ }^{95}$ Piecemeal liquidation of the defendant itself could reduce the total value of its assets..$^{96}$ Such a setting resembles that of a run on the bank, where all fear being last in line; defendants may exploit this anxiety by inducing many to settle early and cheaply. From this perspective, the state court plaintiff's large recovery comes at the expense of the federal court plaintiffs who have patiently refrained from queue jumping. While this view can explain much, it still does not offer a general description, because limited fund cases represent only a minority of all class actions.

A second, darker possibility is that bargaining within the class action plaintiffs' team tends to disfavor the plaintiff with disproportionately high stakes in the action. Plaintiffs whose claimed injuries are near or below the mean may find it expedient to sell out the high stakes plaintiff by negotiating a class settlement with the defendants on a basis that increases the minimum recovery but lowers the maximum recovery per plaintiff. To be sure, the high stakes plaintiff could likewise sell out those with lesser injuries or weaker claims, but typically those individuals having claims with settlement values above the mean will be in the minority. ${ }^{97}$

High stakes plaintiffs may also be disfavored by the predisposition of the jury. Empirical evidence hints that retributive criteria-how much the defendant's conduct shocked the jury-are what chiefly determine the size of the recovery in any action,

8s Intra-plaintiff competition can resemble the standard "prisoner's dilemma" problem of game theory. That is, if the plaintiffs compete among themselves and "race" to a judgment, some plaintiffs will be better off than if they cooperated, and some will be worse off. Risk-neutral plaintiffs would not in theory fear such a competition if it amounted to a zerosum game, but "high stakes" plaintiffs are more likely to be risk averse and thus are those who should fear such a competition most.

${ }^{86}$ Corporations frequently have a "going concern" value that exceeds their asset liquidation value. The excess of "going concern" value over asset value might be lost if the first claimants to recover could require the firm to sell assets to pay their judgments. This argument has long supplied a rationale for the collectivized procedures used in corporate reorganizations. See Thomas H. Jackson, Bankruptcy, Non-Bankruptcy Entitlements and the Creditors' Bargain, 91 Yale L. J. 857, 861-67 (1982).

${ }^{97}$ Several factors suggest that "high stakes" plaintiffs will be a political minority in the large class action. First, most mass disasters will produce more persons with small injuries than major ones (just as the number of wounded ordinarily exceed the number of those killed in any war or battle). See Epstein, $13 \mathrm{~J}$. Legal Stud. at 479-80 (cited in note 6); Weinstein, 11 Colum. J. Envtl. L. at 8-12 (cited in note 7). Second, high stakes plaintiffs are more likely than others to leave the class action to pursue individual claims. Third, the class action attorney who searches for his clients is most likely to find and secure those clients who have otherwise unmarketable claims. 
rather than the aggregate injuries experienced by the plaintiffs..$^{98}$ If juries are more interested in levying retribution than awarding compensation, then the size of the total recovery will be relatively fixed, and high stakes plaintiffs will deplete it disproportionately. In this view, the participation of high stakes plaintiffs does not significantly enhance the size of the class recovery; both they and the other class members will be better off if they opt out (while the defendant is worse off).

Next, the lead plaintiff's attorney for the class may find it in his interest to facilitate a settlement that averages rather than individualizes damages. This attorney has little reason to expend time and energy differentiating the respective strength and settlement value of each claim, particularly if doing so will delay the settlement. The simplest answer from the attorney's perspective is to pay all claimants the same amount-the mean value of their claims. ${ }^{99}$ If we assume that the attorney's primary interest lies in maximizing the overall size of the fund, such an attorney's greatest fear should be that a significant number of plaintiffs will resist the settlement. Thus, the plaintiff's attorney will be willing to sacrifice the interests of the few high stakes plaintiffs in order to placate the majority. ${ }^{100}$ In reality, the opposition is likely to come from "free riding" plaintiffs' attorneys, who may hope too earn fees by convincing the court or lead counsel to restructure the settlement. "Free riding" plaintiffs' attorneys are also likely to represent clients with unmarketable legal claims whom other attorneys have been unwilling to represent on an individual basis; thus, the "common pool" problem also dovetails with that of adverse selection, because so long as there is an incentive for the opportunistic attorney to "free ride," she is likely to obtain only those clients who are unable to monitor or who have been rejected by others.

98 See, e.g., Chin and Peterson, Deep Pockets at 52-57 (cited in note 93).

29 For example, if an accident results in 100 people injured, of whom ninety sustain $\$ 1,000$ in injuries, five sustain $\$ 10,000$, and another five sustain $\$ 100,000$, the mean individual settlement value will be $\$ 6,400$. If a "democratic" vote were taken on whether such a settlement should be approved, the vote might be $90-10$ in favor. For a more realistic example, see notes 104-07, 115-17 and accompanying text.

${ }^{100}$ In the example from note 99 , because the majority of the class is likely to favor a settlement that reduces the variance around the mean settlement value, the attorney could negotiate a settlement whereby, say, the minimum payment would be $\$ 2,000$ and the maximum $\$ 82,000$, and she would easily gain majority approval. The ninety claimants with $\$ 1,000$ in injuries would each be happy to get $\$ 2,000$ and the five with $\$ 10,000$ in injuries would be satisfied with $\$ 10,000$, even though the five with $\$ 100,000$ in injuries would only get $\$ 82,000$. 


\section{The Possibilities for Reform}

The present state of the law with respect to mass tort litigation can fairly be described as chaotic. Several trial courts have accepted a "constructive bankruptcy" theory when the damages alleged exceeded the defendant's assets. ${ }^{101}$ Under this theory, the possible insufficiency of the defendant's assets justifies deeming the corporation to be a "limited fund" and hence certifying the action as a "mandatory" class action from which opting out is not permitted. On appeal, however, most of these decisions have been reversed on various grounds. ${ }^{102}$ The status of the law is further clouded by the Supreme Court's recent decision in Phillips Petroleum Co. $v$. Shutts, which arguably made the right to opt out an element of constitutional due process. ${ }^{103}$ For the present at least, plaintiffs remain able to escape the class action if they-or their attorneys-desire to do so. As a result, races to judgment, disputes over relative entitlements to punitive damages, and the possibility that those last in line will find the defendant's assets insufficient to cover their recoveries will likely persist. In effect, plaintiffs may find themselves in a position analogous to that of the classic prisoner's dilemma in game theory, but compounded by the greater difficulty of achieving a cooperative solution in a game with multiple players.

Mandatory classing does not solve these difficulties because of the uncertain settlement dynamics within the large class action. Increasingly, those plaintiffs who do not opt out of large class actions face courts that engage in damage averaging rather than allocating damages according to the strength of plaintiffs' individual cases. $^{104}$ In some cases, courts have accepted "nuisance value" pay-

101 See, for example, In re "Dalkon Shield" IUD, 526 F.Supp. at 897; Coburn v. 4-R Corp., 77 F.R.D. 43, 45 (E.D. Ky. 1977); In re Agent Orange, 100 F.R.D. at 725-26; In re Bendectin Products Liability Litigation, 102 F.R.D. 239, 241 (S.D. Ohio 1984).

${ }^{102}$ For a concise review of the critical reception this theory has received from appellate courts, see Arthur R. Miller and David Crump, Jurisdiction and Choice of Law in Multistate Class Actions After Phillips Petroleum Co. v. Shutts, 96 Yale L. J. 1, 42, 46-48 (concluding that Agent Orange is the only recent case in which an appellate court has upheld the constructive bankruptcy theory). See also In re School Asbestos Litigation, 789 F.2d 996 (3d Cir. 1986) (reversing mandatory class action certification for punitive damages).

${ }^{103} 472$ U.S. 797 (1985). For review of Shutts's implications, see Miller and Crump, 96 Yale L. J. 1 (cited in note 102).

${ }^{106}$ In some recent antitrust cases, courts have explicitly used a "share-and-share-alike plan of distribution"-despite clear differences in the legal merits among the claims-because the administrative difficulties in assessing the individual claims have made individualized treatment infeasible. See, e.g., In re Corrugated Container Antitrust Litig., 1981 Trade Cases (CCH) \ 64,114 at 76,718 (S.D. Texas 1981), aff'd, 659 F.2d 1322 (5th Cir. 1981); Eovaldi v. First National Bank of Chicago, 71 F.R.D. 334, 337 (N.D. Ill. 1976), rev'd 
ments to subclasses with weak claims on the prudential grounds that an early settlement benefits all. ${ }^{105}$

The growing use of "fluid recoveries" is still another means to the same end result of damage averaging. ${ }^{106}$ In the future, the sheer volume of claims in mass tort cases may leave the courts few practical alternatives to this procedure. Damage averaging is by no means always objectionable. In particular, it seems legitimate in the context of Type B actions: there, the individual stakes are small, and by definition, plaintiffs cannot feasibly opt out. Further, because no claims in a Type B action are independently marketable, there is no objective basis for valuing them individually. Damage averaging may even be justifiable in Type $\mathrm{A}$ actions if the variance among claims is low. But in Type $\mathrm{C}$ actions, where the variance among claims is high, damage averaging is patently unfair to many plaintiffs.

Against this backdrop, what reforms make sense? Is there a way to reduce class action agency costs without overburdening courts with individualized hearings? This article will next survey several policy options-voting rules, the use of subclasses, substan-

on other grounds, 596 F.2d 188 (7th Cir. 1979). Damage averaging also is common in recent employment discrimination cases. See, e.g., Bowe v. Colgate, Palmolive Co., 489 F.2d 896, 902-04 (7th Cir. 1973); Pettway v. American Cast Iron Pipe Co., 494 F.2d 211, 260-63 (5th Cir. 1974); Pettway v. American Cast Iron Pipe Co., 681 F.2d 1259, 1265-67 (11th Cir. 1982); White v. Carolina Paperboard Corp., 564 F.2d 1073, 1087 (4th Cir. 1977). In securities class action settlements, there is a well-established tradition of downgrading the individualized aspects of each plaintiff's case. See In re Equity Funding Corp. of America Sec. Lit., 603 F.2d 1353, 1365 (9th Cir. 1979). See also Note, The Impact of Class Actions on Rule 10b-5, 38 U. Chi. L. Rev. 337, 345-65 (1971). See text at notes 115-17.

Damage averaging is most likely to be accepted by courts and attorneys where the transaction costs of individualizing the damage determination are the highest. In securities cases, where an active market provides daily prices and all losses are measurable in homogenous terms, there is less difficulty in determining damages and hence "split trials" are sometimes used to individualize this determination. See Green v. Wolf, 406 F.2d 291, 301 (2d Cir. 1968). In contrast, mass tort cases present more difficult issues, and hence damage averaging will likely become more common in this context.

${ }^{105}$ See, e.g., West Virginia v. Chas. Pfizer \& Co., 440 F.2d 1079, 1084-88 (2d Cir. 1971), affirming 314 F.Supp. 710, 741-44 (S.D.N.Y. 1970) (\$3 million nuisance award to "secure the agreement" of the sub-class). But see Plummer v. Chemical Bank, 91 F.R.D. 434, 438 (S.D.N.Y. 1981) (denying settlement unjustified by record), aff'd, 668 F.2d 654 (2d Cir. 1982).

${ }^{108}$ See Colson, 59 F.R.D. 324. For a discussion, see Note, 89 Harv. L. Rev. at 1519-23 (cited in note 15). But see In re Folding Carton Antitrust Litig., 744 F.2d 1252, 1254 (7th Cir. 1984) (attempt to use undisbursed portion of settlement fund to create Antitrust Development and Research Foundation rejected by court of appeals). See also Bebchick v. Pub. Utils. Comm'n, 318 F.2d 187 (D.C. Cir. 1963) (en banc); Simer v. Rios, 661 F.2d 655, 675-76 (7th Cir. 1981). In principle, fluid recovery is only damage averaging carried to its logical extreme, such that all potential victims (and others) receive the same financial benefit regardless of their actual injury. 
tive priority rules, cost sharing rules, and judicially developed allocation plans-and then close with a proposed rule that seeks to align the client's and the attorney's incentives.

\section{A. Voting Rules}

A democratic vote of all plaintiffs-the simplest but probably the least effective solution-would probably provide useful protection to minority plaintiffs only in Type A actions. In general, class action plaintiffs do not respond to attempts to ascertain their views, and it is doubtful that those who do respond would understand the issues or questions presented to them. ${ }^{107}$ All the usual factors that produce "rational apathy" in the case of shareholder voting-high information costs, free rider problems, and conflicts of interest, for example - can account for this. ${ }^{108}$ However, class actions present one additional complication: shareholders generally vote according to a rule of "one share, one vote" that roughly reflects their economic stake in the matter at issue. Such a weighted voting system would be both politically and administratively difficult to implement in the class action setting. ${ }^{108}$ Yet, without a weighting system, a numerical majority with a small economic interest-possibly acting under the direction of their self-interested attorneys-could outvote a minority with a much greater stake in the action. Finally, even under a weighted voting system, it is still in the interests of a majority to oppress the minority; only the identity of the majority changes under different voting rules.

${ }^{107}$ In Colson, 59 F.R.D. 324 , only 228 of roughly 40 million class members filed claims against the settlement fund. See Herbert B. Newberg, Newberg on Class Actions § 8, Appendix Table II (2d ed. 1985). Out of thirty class actions surveyed in Newberg in which class members had to file in order to receive benefits, only eight such actions had a response rate of 30 percent or more. Id. $\S 8$, Appendix Tables I and II. For examples of instances in which those responding to a class action notice clearly misunderstood the nature of the proceeding, see Miller and Crump, 96 Yale L. J. at $22 \mathrm{n} .162$ (cited in note 102). To be sure, these problems will be most pronounced in a Type B or $\mathrm{C}$ class action, and voting may be a more feasible safeguard in a Type A class action, but it may not possible clearly to distinguish these two contexts.

${ }^{103}$ See Robert Clark, Corporate Law 389-94 (1986) (reviewing these problems in shareholder voting).

${ }^{309}$ If plaintiffs were given voting rights in proportion to the value of their claims, they would have an incentive to inflate the value of their claims. In bankruptcy reorganizations, where voting is proportionate to the value of claims, only those having "allowed" claims may vote. See 11 U.S.C. $\$ 1126$ (a) (1982). In class action settlements, however, no procedure exists to decide which claims should be allowed before the settlement approval. Typically, the court determines damages only after it resolves liability issues, and settlements almost by definition precede determination of liability. 


\section{B. The Use of Subclasses}

Traditionally, the law's primary means of preventing exploitation of minority plaintiffs has been to divide class action plaintiffs into subclasses, thus giving each subclass the power to approve or reject the settlement as it applies to it. This mitigates but does not eliminate the foregoing problems. Logically, inter-plaintiff conflict and adverse selection should persist within each subclass where plaintiffs whose claims have an expected value above the subclass mean still have an incentive to opt out. Of course, if there are enough subclasses, the variance around the mean in each may be made small enough to eliminate opting out. This would be the result if the transaction costs associated with opting out came to exceed the increase in recovery that any plaintiff could expect in an individual action. Still, because the use of multiple subclasses increases the both number of attorneys involved and thus the inevitable transaction costs, it is indeterminate whether subclassing really reduces private costs.

Further, the greater the number of subclasses used, the greater the extent to which bargaining among subclasses approximates bargaining among individual plaintiffs in actions without subclasses and hence increases uncertainty as to who will form the dominant coalition. Bargaining among even a limited number of multiple subclasses is unstable. Myriad coalitions can be formed and bargains struck. For example, those subclasses with the highest and lowest expected claim value could negotiate for high minimum payment and maximum payments but a comparatively low mean payment, thereby disadvantaging average claims. Conversely, those holding claims of average value would prefer a high mean with a low ceiling on the maximum payment for more serious injuries. This jockeying for position, like the struggle for the lead counsel designation, may explain the growth of nationwide litigation networks that today link plaintiffs' attorneys handling individual actions involving the same subject matter in different forums. ${ }^{110}$ This network represents a "second best" means of reducing transaction costs without the attorney risking loss of control over her action (as she would were the actions consolidated).

110 For early accounts of the development of litigation networks, see Paul D. Rheingold, The MER/29 Story-An Instance of Successful Mass Disaster Litigation, 56 Cal. L. Rev. 116 (1968); Paul D. Rheingold, Mass Disaster Litigation and the Use of Plaintiffs' Groups, 3 Litigation 18 (Spring 1977). For a more recent account, see Marc Galanter, Lawyers' Litigation Networks (unpublished 1985). 


\section{Substantive Allocation Rules}

The position of the "high stakes" plaintiff in the large class action is not unique, but rather is paralleled in other organizational settings. For example, the individual whose injuries justify a higher than average recovery is in much the same position as skilled workers in an industrial plant whose wage demands-which the employer would accept because of the high productivity of these workers-are subordinated to the wage demands of unskilled workers who constitute the voting majority in the bargaining unit. ${ }^{111}$ Similarly, in the negotiations among the multiple creditor classes in a bankruptcy proceeding, it has long been thought that the interests of secured creditors are often sacrificed in favor of unsecured creditors. ${ }^{112}$ In response, federal labor law places limits on the composition of bargaining units in order to protect skilled workers from being submerged within an unskilled bargaining unit. ${ }^{113}$ Likewise, federal bankruptcy law long recognized rules giving "absolute priority" to senior claimants in the bankrupt estates. ${ }^{114}$

${ }^{111}$ See Mayer F. Freed, Daniel D. Polsby, and Matthew L. Spitzer, Unions, Fairness and the Conundrums of Collective Choice, 56 So. Cal. L. Rev. 461, 477 (1983); Matthew W. Finkin, The Limits of Majority Rule in Collective Bargaining, 64 Minn. L. Rev. 183, 218-21 (1980). One study of the United Auto Workers found a significant deterioration in the wages of skilled workers relative to unskilled workers where both groups were jointly represented. See Robert M. MacDonald, Collective Bargaining in the Automobile Industry 158 (1963). Freed, Polsby, and Spitzer cite the case of the American Federation of Musicians, which for thirteen years did not negotiate for wage increases for one group of skilled musicians (recording artists) and instead sought increases for workers in lower paying jobs. Freed, Polsby, and Spitzer, 56 So. Cal. L. Rev. at 477.

112 See Brudney and Chirelstein, Corporate Finance at 123-74 (cited in note 35); Douglas G. Baird and Thomas H. Jackson, Cases, Problems and Materials on Security Interests in Personal Property 560-62 (2d ed. 1987). The conventional wisdom has been that junior creditors could cause delay and expense to the senior creditors sufficient to convince the senior creditors to settle for less than their full contractual rights. Also, an agency cost problem exists: the investment bankers who organize the reorganization creditors committees tend to be more closely aligned with management and the equity classes.

${ }^{113}$ For example, professional employees cannot be placed in a nonprofessional bargaining unit without their consent. Labor Management Relations Act, 29 U.S.C. $§ 159(\mathrm{~b})(1)$ (1982). See Freed, Polsby, and Spitzer, 56 So. Cal. L. Rev. at 477-78 (cited in note 111).

114 The Supreme Court adopted an "absolute priority" rule under which no junior claimant could receive anything in reorganization unless and until all senior creditors were first paid in full. See Case v. Los Angeles Lumber Prod. Co., 308 U.S. 106 (1939). This rule was legislatively modified to permit a plan not approved by the class still to be judicially approved under the more rigorous "cramdown" provisions which require a judicial fairness review. See 11 U.S.C. $\$ 1129$ (b) (1982). To be "accepted," a bankruptcy reorganization plan must be approved by the holders of two-thirds of the dollar value of allowed claims and by a numerical majority of elaimants. See id. $\S \S 1126-29$. These procedures obviously reflect some distrust of simple majoritarian voting. 
In effect, these rules reflect a distrust of democratic solutions in contexts that parallel that of the class action. Intuitively, we may feel that the most seriously injured in a mass tort case should receive full (or at least substantial) compensation before those less seriously injured. Especially where the claims against the debtor vastly exceed its assets, simple proration of all claims may produce injustice. In such cases, it may be more equitable that those worse off receive nearly full compensation than that all receive, say, 10 percent of the judgments owed them. Yet a natural scale of priorities is lacking. Even if we feel that a few clear categories-for example, decedents and those totally disabled-should rank at the top of such a scale, their greater injury was probably already reflected in a higher judgment. In general, it is difficult to put principled limits on this sort of prioritization. Equitable considerations rarely lead to hard and fast rules that apply across a broad category of cases, particularly in fact-specific mass tort cases. For example, should the plaintiff who is 50 percent disabled receive nothing until those who have been totally disabled receive full compensation-even if those who have been totally disabled might face significant difficulties in proving causation?

\section{Judicially Devised Settlement Plans}

If private bargaining within the plaintiffs' camp will not produce an equitable allocation of the recovery, another alternative is to allow plantiffs' attorneys to litigate or negotiate settlement for the total amount of damages, but to reserve allocation of damages among the plaintiffs for the court. The court might delegate the allocation to a special master, as Judge Weinstein did in the Agent Orange litigation. ${ }^{115}$

Indeed, the Agent Orange cases provide an excellent illustration of both the potential for judicially devised distribution plans and the problems with relying on such a remedy. Essentially, Judge Weinstein first approved a $\$ 180$ million settlement plan and then appointed a special master, Kenneth Feinberg, to develop a plan for its distribution. Under the master's plan, which the court approved, "only totally disabled veterans will receive individual cash awards." "I6 In effect, the court denied any individual compen-

115 See In re Agent Orange, 611 F.Supp. 1396.

116 Id. at 1410 . Totally disabled veterans were to receive approximately $\$ 12,000$ each. This aspect of the plan was upheld on appeal. In re Agent Orange Product Liability Litigation, 818 F.2d 179, 183-84 (2d Cir. 1987). See also Arnold H. Lubasch, $\$ 200$ Million Agent Orange Award Is Upheld by U.S. Appeals Court, N.Y. Times B3, col. 5 (Nat'l Ed. April 22, 
sation to those whose injuries did not rise to the level of total disability, even though the causal linkage between their injuries and exposure to Agent Orange might have been far clearer. In fact, Judge Weinstein rejected a formula proposed by the plaintiffs' attorneys that would have factored in the relative litigation strength of each plaintiff's case. As he acknowledged, the plaintiffs' attorneys had proposed an "essentially tort-based compensation scheme" which sought to discount each plaintiff's recovery in light of the differing probabilities that the plaintiff's injuries were truly caused by Agent Orange. ${ }^{117}$ Instead, Judge Weinstein adopted what amounts to a moral absolute priority rule, which focused only on the extent of the injury and disregarded the strength of each plaintiff's individual case.

Is such a rule of priority appropriate simply because the total fund was too limited to pay all claimants? As a general matter, plaintiffs who are 75 percent disabled may understandably believe it is unfair that they receive nothing when their injuries were only slightly less severe and may have been more directly related to the defendant's conduct. Still, although abrupt discontinuities in treatment are seldom justified, the special facts in Agent Orange, where no plaintiff would receive more than $\$ 12,000$, may have justified the court's unique distribution plan because any attempt to include more plaintiffs within the plan would have simply trivialized the recovery to all. At best, judicial distribution plans seem a second best solution, and few general rules can be formulated to guide courts across a broad array of cases.

What is even clearer about judicially devised distribution plans, however, is that they create uncertainty. A "high stakes" plaintiff in a Type $\mathrm{C}$ action may thus have no idea at the time the settlement is proposed whether she should favor or oppose it, because she does not know how the fund will be distributed. For the conscientious attorney, the problem is the same: how can the attorney recommend that her clients opt out or accept the settlement when she cannot predict the real effect of the settlement until the court devises a distribution plan? In this light, the likely effect of this uncertainty may be to increase the rate of opting out by high

1987).

117 In re Agent Orange, 611 F.Supp. at 1407-08. The court found that the cost of establishing an "individual discount factor" for each plaintiff would have been "enormous" and prohibitive. It is not clear, however, that such an individual calculation is necessary; only "high stakes" plaintiffs will, after all, have sufficient incentive to challenge an averaged award for the class or subclass. 
stakes plaintiffs, who will predictably seek to preserve their rights from judicial benevolent paternalism.

One answer to this quandary would be to permit plaintiffs to opt out when the special master proposes the distribution plan. As a practical matter, only high stakes plaintiffs could credibly threaten to opt out. Yet, their threat to do so might well influence the distribution of the recovery in their favor as the court sought to achieve a global settlement and avoid costly, multiple suits. Indeed, because a high rate of opting out might also cause the defendants to withdraw from the settlement, the court would have a further incentive to tilt damage allocation towards those who could credibly threaten to opt out. Viewed in this light, the existing pattern is turned on its head, and the problem becomes not that the high stakes plaintiffs will be exploited, but that they could arguably acquire too much leverage.

\section{E. Taxing the Free Rider}

In Agent Orange, Judge Weinstein suggested another means of reducing the rate of opting out: those plaintiffs who seek to opt out might be assessed a pro-rata share of the discovery costs incurred by the class at the time they seek to use the discovery materials assembled in the class action. ${ }^{118}$ Obviously, this proposal responds directly to the free rider problem that opting out engenders. Still, it can be both an excessive and an inadequate response. Used aggressively by the district court hearing the class action, this power to tax the opting out plaintiff might succeed in precluding all opting out, particularly in view of the asymmetric stakes factor that constrains the plaintiff's attorney's willingness to invest in the action. Used more modestly, it may prove inadequate to offset the incentives for the plaintiff's attorney to opt out when the attorney recognizes that she can earn a substantial 40 percent contingency in a "tag along" individual action but virtually nothing if her client remains in the class action. Procedurally, such a cost sharing rule may be difficult to implement because total discovery costs will not be known at the outset when many plaintiffs will opt out; thus, the tax may remain uncollectable unless and until the class action is successfully settled or litigated to a judgment.

\section{F. A Proposal to Control Opt-Outs}

As we have seen, the right to opt out has several faces. On the 
one hand, opting out may be motivated by the attorney's desire to obtain a higher fee-even at the expense of her client's interests. The client also may have a perverse incentive to threaten to opt out as a way to disrupt intra-class settlement bargaining and earn a larger share of the recovery than his claim merits. From a public law perspective, opt outs may precipitate a rush to judgment and necessarily increase public costs through multiple suits. On the other hand, opting out can be the plaintiff's one indispensable protection against exploitation by other class members.

A sensible first step toward reducing the rate of opting out would be to deny opting out plaintiffs any right to punitive damages. This compromise could be achieved by certifying a mandatory class for punitive damages only, but permitting plaintiffs to opt out for compensatory damages. Such a tradeoff recognizes both the injustice in treating unlike cases alike-as the class action may sometimes do-and the fact that punitive damages, as a windfall imposed for deterrent purposes, do not "belong" to anyone. ${ }^{118}$ This compromise would thus mitigate the pressure to settle inherent in cases like Hyatt Skywalk, because plaintiffs who file in state court would know at the outset that they had no right to punitive damages.

By itself, this proposal may seem inadequate. First, it still leaves defendants exposed to a multiplicity of cases in which exemplary damages will be imposed by "heart throb" juries. In this view, the defendant needs protection from the "tyranny of small decisions," where individual juries in separate cases grant numerous multimillion dollar judgments based more on their retributive assessment of the defendants' conduct than on a compensatory evaluation of the plaintiff's injuries. A logical answer to this problem, however, would be to give the bankruptcy court discretionary authority to scale down tort judgments on an ex post basis to reflect average recoveries in all actions. To an uncertain extent, they may already possess such a power. ${ }^{120}$ Although much commentary

118 See Clarence Morris, Punitive Damages in Tort Cases, 44 Harv. L. Rev. 1173, 1177 n.7 (1931); Note, 96 Harv. L. Rev. at 1145-46 (cited in note 7). See also deHaas v. Empire Petroleum Co., 435 F.2d 1223, 1231-32 (10th Cir. 1970) (noting desirability of creating a common fund in which all plaintiffs would share in punitive damage award, but finding precedent lacking).

${ }^{120}$ An unsettled area of bankruptcy law involves the authority of the court to approve a plan of reoganization that "classifies" unsecured claims into different classes that are then treated differently under the plan. The significance of this area of law to mass tort cases becomes clear if we hypothesize a corporate reorganization plan that classified awards of punitive damages into a different class from tort judgments that involved only compensatory damages and then proposed to pay, say, 90 percent on all compensatory judgements 
has objected to corporate defendants resorting to bankruptcy to scale down tort claims, ${ }^{121}$ the early evidence indicates that corporate managements have lost more than they have gained from this tactic and now are unlikely to resort to it, at least if viable alternatives exist. ${ }^{122}$ One attraction of this proposed power to scale down punitive damages ex post is that in practice it would come into operation only when the corporation makes the reluctant decision to file for bankruptcy. Thus, it avoids the danger that the corporation was only "crying wolf" when it complained that high recoveries in state court were driving it to bankruptcy. Arguably, such judicial adjustments ex post would give greater attention to issues of distributive fairness.

The second and greater failing of any proposal that does not directly focus on the plaintiff's attorney is that the rate of opting out will remain unacceptably high so long as the plaintiff's attorney can realize a higher fee recovery in individual state court actions. The direct answer to this problem is to make the plaintiffs' attorneys bear some of the costs that their decisions to opt out impose on their clients and society. The most logical means to this end would be to structure the plaintiff's attorney's fee in "opt out"

but only 50 percent on the punitive damage judgments. This would provide a means to an ex post scaling down of disproportionately high tort judgments so as to treat similarly situated pläintiffs similarly with respect to a limited fund. It would also reduce the pressures for a race to judgment based on the prospect that punitive damages would be available only to those who secured the first judgment or settlement. Under § 1123(a)(1) of the Bankruptcy Act, the court is authorized to classify claims under Chapter 11, but this power may be subject to equitable limitations such as the unfair discrimination test in $\S 1322(b)(1)$, which technically applies only in Chapter 13 but which may lead courts to adopt a similar standard under Chapter 11. See 11 U.S.C. $\$ \S 1123(a)(a), 1322(b)(1)$ (1982). See also Barnes v. Whelan, 689 F.2d 193 (D.C. Cir. 1982) (prohibiting classifications that unfairly discriminate in Chapter 13 reorganizations). In my judgment, such a power to classify and scale down disproportionate claims would make the bankruptcy court an attractive forum for achieving equity among the plaintiffs' class. Conceivably, a plan could even classify that portion of a debt that exceeded a specified level (say $\$ 1$ million) into a separate class and reimburse a lower proportion of this excess. Thus, while some critics have objected to the use of the bankruptcy courts as a forum for resolving mass tort claims, see Note, The Manville Bankruptcy: Treating Mass Tort Claims in Chapter 11 Proceedings, 96 Harv. L. Rev. 1121 (1982), I believe this forum has a still unexplored potential.

121 David Rosenberg, The Dusting of America: A Story of Asbestos-Carnage, Coverup, and Litigation, 99 Harv. L. Rev. 1693, 1693 n.3 (1986). But see Note, Cleaning Up in Bankruptcy: Curbing Abuse of the Federal Bankruptcy Code by Industrial Polluters, 85 Colum. L. Rev. 870 (1985).

${ }^{122}$ See Cynthia F. Mitchell, Negative Verdict: Manville's Bid to Evade Avalanche of Lawsuits Proves Disappointing, Wall St. J. 1, col. 7 (July 15, 1986). Although Manville had expected to "emerge bulletproof in 18 months," it has instead remained in reorganization for over four years, seen its top management replaced as a result, and will be required to place as much as 80 percent of its stock in a trust fund for victims. Id. 
actions so that it became a percentage of the margin, if any, by which the client's recovery in the individual action exceeded the client's proportionate share in the class action. This would place the plaintiff's attorney at risk for opting out; the attorney would earn a fee only if she outperformed the class and thus vindicated the decision to opt out. Although this solution does not go to the logical extreme of forcing the attorney to bear the adversary's costs or the public costs, full fee shifting seems an excessive measure given the unavoidable fact of asymmetric stakes. Because the plaintiff's attorney expects to receive only a fraction of the client's recovery and frequently enjoys a litigation cost differential, the attorney's potential liability for losses is far greater than her expected gain from the action and thus full fee shifting might deter her from opting out even when opting out would serve the client's interest. To a degree, the arguments here parallel those for and against fee shifting under Rule 68 of the Federal Rules of Civil Procedure, where current practice merely denies post-settlement offer fees when the actual recovery does not exceed the rejected offer, but does not impose liability for the offering party's postoffer costs. ${ }^{123}$ No reason is apparent to be more harsh on the attorney in this context than under Rule 68.

Still, this proposed fee formula would be considerably harsher on the attorney who opted out than is the current system. Today, only a few decisions have inhibited the attorney's ability to opt out in a mass tort action, and only those decisions that have sought to tax the opting out plaintiff for a share of the discovery costs incurred by the class constitute any real chill for the future, given the generally hostile reaction that attempts to certify a mandatory class action have received at the appellate level. ${ }^{124}$

This proposed treatment of attorneys who opt out may be criticized as impractical. First, there is a timing problem: the individual recovery may precede the class recovery-and indeed would be more likely to do so if this would avoid the rule's application. A possible response would be to give the client a nonwaivable statutory right to recoup, for a limited period after the class action's resolution, that portion of the fee that was earlier paid but not justified under this standard. A more practical response would be for the federal court to enforce this rule by requiring the plaintiff's

${ }^{123}$ No case has ordered fee shifting against the plaintiff pursuant to Rule 68 , and at least one decision has rejected this possibility. See Adams v. Wolf, 110 F.R.D. 291 (D. Nev. 1986).

124 See note 102. 
attorney who opts out either to certify to it at that time that she will return any "excess" fees under this formula, or to require the actual deposit of such fees in escrow with the court. ${ }^{125}$ Judge Weinstein in the Agent Orange litigation suggested perhaps the simplest way to implement such a rule: require counsel in the "opt out" actions to report any fees received by them "so that an appropriate percentage could be ordered paid to the class, which bore the expense of joint discovery."128 This "charge back" rule, however, may still leave an excessive incentive to opt out, because the court is only prorating discovery costs among the actual and putative class members; it is uncertain whether such costs would approach the 30 to 40 percent of the recovery that some attorneys charge on a contingent fee basis in individual actions. ${ }^{127}$

A final objection to my proposed attorney fee rule is that the client who wishes to opt out might find it difficult to secure legal services if fees were forfeitable. Although this is a more serious concern, it seems difficult to believe that, in a legal market that is increasingly deep and active, the determined client could not find an attorney willing to take her case if the action seemed likely to produce an above-average recovery. In principle, the client is similarly restrained by legal rules that limit the maximum contingent fee that may be charged. In any event, an exception could certainly be created to permit the client to pay the attorney on a non-contingent fee basis, because the client then would have knowingly assumed the risk and the attorney would no longer be functioning as an independent entrepreneur.

The key point about this proposed rule is that it does not chill the client's desire to opt out, but only the attorney's; thus, it should not be viewed as abridging any constitutional or other legal right to opt out that the client may possess. Ultimately, it is a response to market failure in the market for legal services, because it forces the attorney to decide whether opting out will benefit the client. To be sure, it imposes some additional risk on the attorney,

${ }^{125}$ This solution would probably not run afoul of the Anti-Injunction Act, 28 U.S.C. $\$ 2283$, because the actual proceeding in state court is not enjoined, directly or indirectly. See note 79.

${ }^{128}$ In re Agent Orange, 611 F.Supp. at 1317. See also the cases cited in note 81. Judge Weinstein indicated that he preferred a "more equitable" alternative-namely, "to assess the amounts to be paid by opt-out plaintiffs at the time that they make use of MDL discovery materials, regardless of the outcome in their individual cases." 611 F.Supp at 1317. This alternative might operate as a stay against opting out, unless the attorney did not need access to the discovery materials. At worst, this alternative might encourage duplicative discovery.

${ }^{127}$ See notes 11 and 31. 
but little more than is inherent in the conventional contingent fee, which also makes the attorney a joint venturer with the client. In short, its leading attraction is that it mimics the results that hypothetical bargaining in an informed market would produce.

\section{Conclusion: Redefining the Tradeoffs} AND AN AgEnda For REForm

Essentially, this article has been about two different kinds of costs-"agency costs" and "public costs"-and the tradeoffs between them. Proponents of mandatory class actions properly argue that such actions reduce the public costs associated with duplicative litigation. In addition, because they concentrate greater resources on a single proceeding, they arguably increase the likelihood of accurate factfinding at trial. ${ }^{128}$ But what these proponents have ignored is that measures that reduce public costs may also increase agency costs-most notably because of the "common pool" and adverse selection problems. In this light, the savings in public costs associated with mandatory class actions may derive to some unknown extent from economizing on the costs necessarily associated with fairly allocating damages among the plaintiffs. There is then an invisible efficiency/fairness tradeoff in the damage allocation issue, which proposals for bureaucratic justice tend to slight. Whether we depend on benevolent judicial paternalism, as in Agent Orange, or depend on the unstable dynamics within the large class action to allocate the recovery within the class, the expected outcome for the individual plaintiff with a legally marketable claim becomes highly uncertain. As a result, this plaintiff's agency costs are increased substantially.

Agency costs can, of course, be reduced by entitling the plaintiff to opt out as a matter of right, as suggested by Shutts. But even from a private law perspective, this answer is hardly a panacea, because it exposes the client to attorney opportunism. From a public law perspective, it is an even worse disaster because it leads back to duplicative litigation. It may also lead to underdeterrence, although this is more questionable since recently defendants often have been the parties seeking mandatory class certification.

Given this uncertain tradeoff between agency costs and public costs as well as the constitutional obstacles Shutts may place in

${ }^{128}$ See Richard A. Posner, Economic Analysis of Law $\S 21.8$ at 532-33 (3d ed. 1986) (predicting "bigger cases [are] decided correctly a higher proportion of the time than smaller cases"). 
the path of expanding the mandatory class action, what type of reform makes the most sense? The private law ideal is that the attorney act as would a client able to make a fully informed choice. Compensating the opting out plaintiff's attorney according to how much the attorney outperforms the average recovery to the class or subclass approximates this result-albeit imperfectly. ${ }^{129}$ In principle, this approach should not run afoul of Shutts, because it will only cause the attorney to act as the client would have wanted and is not a device to chill any plaintiff's right to opt out. To be sure, we cannot truly know what the actual client would want if fully informed, but a hypothetical bargaining approach seems the best means to approximate this outcome.

Some will predictably reply that a hypothetical bargaining game is too indeterminate to serve as a guide to public policy formulation. Still, within limits, I believe we can confidently predict how rational clients and attorneys would bargain over the opt out issue if we assume that both parties understand that the attorney possesses asymmetric information and that they are bargaining over a "one time only" transaction. Under these assumptions, when the attorney recommends to the client that they opt out of the class action, the rational client would understand that the attorney may be behaving opportunistically in recommending this course of action. Because the client knows that she cannot distinguish valid legal advice from self-serving attempts to maximize legal fees, the client's rational response should be to demand some form of warranty to ensure that the attorney cannot profit at her expense. In a hypothetical world of rational bargaining, attorneys would also recognize this problem and signal their good intentions by offering to structure their compensation so as to bet on their own success. In standard economic parlance, this is called "bonding," and it is the quintessential means of reducing agency costs.

All contingent fee agreements are in this sense a form of bonding, but they are also something more. They are also a risk sharing arrangement that sensibly shifts risks from presumptively risk averse clients to relatively risk neutral attorneys. As a repeat player, the entrepreneurial attorney can diversify risk by carrying a portfolio of actions. Although any contingent fee arrangement shifts risk to the attorney, the class action provides a baseline for attorney-client risk allocation in the decision to opt out: the client

${ }^{128}$ Even under this marginal fee structure, the attorney will wish to reject some settlements-namely, those just above the average class recovery level where the compensation to the attorney is small-that the client would accept. 
has the opportunity of cheaper representation and more predictable recovery as a member of the class. To induce clients to opt out, attorneys should offer to bear even more risk by bonding themselves to outperform the class action.

From a public law perspective, this proposal resembles Rule 68 of the Federal Rules of Civil Procedure in seeking to shift private costs so as to minimize public costs. In effect, the individual client's decision to opt out can impose costs on other plaintiffs, the judicial system, and the defendants. To internalize these external costs, this proposal treats the existence of a certified class as the equivalent of a defendant's settlement offer under Rule 68. Unlike Rule 68, which may only reduce the settlement offer and not the volume of litigation, ${ }^{130}$ this proposal should reduce the volume of duplicative litigation by reducing the incentive for opportunistic opting out. Still, this approach is probably less draconian than Judge Weinstein's suggestion in Agent Orange that the client who wishes to opt out should be immediately taxed for an appropriate share of the class counsel's discovery costs; the power to tax is potentially the power to destroy, and opting out thus could be excessively chilled. Although the plaintiff's attorney could be asked to pay this tax on behalf of the client, taxing opting out at the commencement of the litigation ignores the problems of asymmetric stakes: many plaintiff's attorneys cannot finance protracted litigation. If instead we charge the plaintiff's attorney with a share of the discovery costs incurred by the class and deduct this amount at the fee award stage from his fee, then Judge Weinstein's cost sharing proposal in Agent Orange begins to resemble the marginal fee formula I have proposed.

The feasibility of either proposal depends, however, on a single court having authority to monitor all fees and to prevent free riding by those opting out. Necessarily, the court hearing the class action must have authority over the fees charged in related individual actions, even if they are separately tried in state court. The ingenuity of Judge Weinstein's proposal is that it recognizes that the court already has considerable authority based on its control over the discovery materials assembled in the class action.

Assuming the court can by some means regulate the fees received by opting out attorneys, what level of fees should be permissible? So far, I have argued only that the fee should be based on

130 Several commentators have doubted that Rule 68 will reduce the volume of litigation because it should only cause defendants to lower their settlement offers. See, e.g., Geoffrey P. Miller, An Economic Analysis of Rule 68, 15 J. Legal Stud. 93 (1986). 
the margin, if any, by which the attorney outperforms the class recovery. Because opting-out attorneys bear more risk under such a formula, they arguably deserve a higher percentage than that typically received by class counsel. But how high a percentage is justified? From a private law perspective, very high percentages can be defended if they still leave the client better off as a result of opting out. But the private law perspective does not consider public costs. From an economic perspective, a price is a signal. ${ }^{131}$ If an informed, rational client offered to pay a very high contingent fee to an attorney, this may signal the inherent weakness of her claim. ${ }^{132}$ Even if rational clients are willing to pay such a fee, it is questionable whether society should bear the public costs of "long shot" actions. Hence, by placing a ceiling on the maximum permissible percentage the attorney can receive, we do not necessarily protect clients, but we probably do economize on public costs and winnow the queue at the courthouse door by chilling longshot actions. ${ }^{133}$

The interdependence of price and quality has significance both for the control of opting out and for the regulation of the market for legal services generally. Courts seldom, if ever, permit contingent fees to exceed 50 percent of the recovery. The conventional justification for this restriction-that it protects the client from overreaching-ignores the risks borne by the attorney as entrepreneur; perhaps the high price is justified by high costs and the low probability of success. A better justification for any ceiling on the percentage-of-recovery fee is that such a limit functions both as a crude restriction on attorney quality and as a rationing device that protects the judicial system from unjustified high public costs in long shot cases. Similarly, it protects other litigants by purging the courthouse queue of its risk preferring gamblers.

Finally, this view of price as a signal also helps us understand why the most obvious answer to the "common pool" problem will not work. One could in theory auction the right to represent the class, awarding it to the attorney willing to accept the lowest fee award. Yet, if price is a signal of quality, the auction may be flawed. The lowest bidder may be a poor quality attorney with the lowest opportunity cost, or the attorney most prepared to settle on a collusive basis against the plaintiff's' best interests.

131 See Joseph E. Stiglitz, The Causes and Consequences of the Dependence of Quality on Price, 25 J. Econ. Lit. 1 (1987).

132 Id. at $16-18$ (on standard adverse selection).

${ }^{133}$ Id. at $23-24$ (on price as a product quality signal). 
Given the need to focus on both private and public costs, and the uncertainty of the tradeoffs between them, what other reforms strike a sensible balance in this context of entrepreneurial litigation? Sound public policy analysis should recognize that multiple fora increase public costs more than multiple actions. Thus, if the law were to permit the high stakes plaintiff to opt out of the class action but insist that this plaintiff remain before the same court, incremental public costs might be modest. Economies of scale and specialization would continue; only one judge would have to become familiar with the complex facts in the dispute; pretrial discovery would remain consolidated. Equally important, one court would have some knowledge of all the consolidated cases, minimizing the "race to judgment." Finally, the marginal fee formula I propose is probably only feasible when one court hears both the class and individual actions.

Interestingly, little tinkering with existing practices is necessary to implement such a reform because individual "tag along" cases today rarely escape the forum to which they are transferred for consolidated pretrial purposes..$^{134}$ Only those actions filed in state courts before the class was certified are likely to escape the consolidation mechanism. In this light, the most needed reform is not extending the scope of the "mandatory" class action, but rather extending the reach of the consolidation process. Admittedly, authorizing the Panel on Multidistrict Litigation to transfer state cases to federal court would infringe on state autonomy and may sometimes involve "distant forum" problems, but such authority could be discretionary and subject to limits. In any event, the alternative of mandatory class actions infringes even more intrusively on client autonomy.

Ultimately, the critical barrier for entrepreneurial litigation is the "common pool" problem; to rationalize this form of litigation, courts must respond more sensibly to the peculiar institution of the "ad hoc plaintiffs' firm." Decisions that refuse to recognize this concept, or that disallow fee redistributions within such a firm, only encourage intra-plaintiff competition and preclude generally advantageous private ordering solutions. From an efficiency standpoint, the "ad hoc firm," however unstable it is today, has several advantages over its nearest competitor, the litigation network: (1) it permits more efficient diversification by allowing attorneys to spread their risk, (2) it simplifies financing the large class action,

${ }^{134}$ See Note, The Experience of Transferee Courts Under the Multidistrict Litigation Act, 39 U. Chi. L. Rev. 588, 607-08 (1972). 
and (3) it should produce superior monitoring within the plaintiffs' team by introducing knowledgeable "investor" attorneys to play the informed role that clients cannot. Thus, because of the superior monitoring it affords, the "ad hoc firm" could potentially be developed into an important "market mimicking" strategy. Ideally, to encourage its development through internal contracting, the fee award might go directly as a lump sum to the plaintiffs' firm without judicial distribution among the attorneys. ${ }^{135}$ At least as a first step, courts should be tolerant of arrangements that the plaintiffs' attorneys adopt among themselves to finance the action. Even if, as in Agent Orange, one group of attorneys appears to have overreached another, it does not necessarily follow that the client's interest will suffer. The court's role in class actions is to protect the client who cannot protect himself, not to protect the attorney who has misjudged the consequences of her own agreement. Beyond an obligation to disclose fee sharing arrangements to the court in order to ensure that those in control of the action do not have an excessive incentive to settle it quickly, little more regulation of fee arrangements among attorneys seems necessary. It seems a safe presumption that the efficiency benefits of fee sharing arrangements among attorneys generally outweigh their disadvantages: attorneys agree to them for just that reason.

However, the choice of lead counsel should be an exception to the rule of benign judicial neglect of arrangements among attorneys. In effect, this decision confers an important property right, the right to manage and control the class action, and how this right is awarded necessarily mitigates or aggravates the "common pool" problem. In choosing lead counsel, courts should distinguish between contexts where attorney search costs are important to the raising of a claim and those where they are not. When a search is important-as, for instance, in some mass tort cases-control of the action should go to the attorney who principally researched and prepared it. Ordinarily, as a practical matter, this means a presumption in favor of the attorney who first files the action. This policy resembles that underlying the patent laws and will encourage investigation of potentially meritorious causes of action. In

${ }^{135}$ Some decisions have accepted this procedure of a lump sum payment to the plaintiffs' management committee. See In re Magic Marker Securities Litigation, [1979 Transfer Binder] Fed. Sec. L. Rep. (CCH) I 97,116 at 96,195 (E.D. Pa. 1979); Valente v. Pepsico, Inc., [1979 Transfer Binder] Fed. Sec. L. Rep. (CCH) I 96,921 at 95,893 (D. Del. 1978); In re Ampicillin Antitrust Litigation, 81 F.R.D. 395, 400 (D.D.C. 1978). Still, the Second Circuit panel squarely rejected this possibility in Agent Orange. See note 59. 
other contexts-like antitrust class actions where private enforcers often piggyback on a prior governmental action-search by private attorneys is less important, possibly because the government can engage in lower cost search through its unique engines of discovery, such as the grand jury. Here, the law should discourage opportunistic behavior by awarding the action to the attorney who is both competent and most likely to be monitored closely by an active client. Other things being equal, these factors point toward a presumption that the client with the largest stake in the action is the best monitor. Above all, courts should avoid elections among the participating counsel or similar techniques for choosing lead counsel because they encourage investment in rent seeking activity. ${ }^{136}$

Candor requires the admission that the preference expressed in this article for retention of a greater measure of individualized justice than recent proponents of "bureaucratic justice" have urged may prove very costly. The efficiency justifications for restricting duplicative litigation may prove to outweigh the fairness values underlying a broad right to opt out. In related contexts, Congress has sometimes explicitly subordinated the interests of one sub-class to another in order to make the overall system work. ${ }^{137}$ Yet, we should recognize the consequences of such a decision: not only do we subordinate the goal of compensation to the goal of deterrence, but we risk converting private litigation into a system for judicially mandated wealth transfers. In some contexts, this may be justified; in others, not. Accordingly, considerable care and attention should be given both to defining the context narrowly and to making certain that the claimed efficiency gains cannot be realized almost as well by less restrictive alternatives. Before our system of private law accepts mandatory classing, damage averaging, or crude majoritarian rule, less drastic means-such as fee incentives, consolidation procedures, and even the use of alternative forums such as the bankruptcy court-need to be better explored. Individualized justice may be less costly than we think, because those with unmarketable claims should not opt out.

This article began by emphasizing the fact of market failure in the special submarket for class action legal services. Market failure presents us with essentially three choices: (1) we can continue to

${ }^{138}$ See Private Attorney General (cited in note 1).

${ }^{137}$ See Freed, Polsby, and Spitzer, 56 So. Cal. L. Rev. at 477-78 (cited in note 111) (subordination of the interests of skilled workers to those of unskilled was accepted by Congress as a necessary price of efficiency). 
repress the fact of entrepreneurial litigation, thereby denying legal services to some and hindering the ability of plaintiffs' attorneys to finance or organize the large class action; (2) we can adopt a pervasive system of bureaucratic regulation, thereby benefiting some but typically not those with the most at stake; or (3) we can attempt to reduce agency costs by intelligent manipulation of incentives. Decisions such as the Supreme Court's in Delaware Valley Citizens' Council and the Second Circuit's in Agent Orange seem to be pursuing the first option, ${ }^{138}$ while the elaborate case law on the lodestar formula at the court of appeals level represents a partial institutionalization of the second approach-one that has already created the equivalent of a judicial system of utility regulation. Sadly, the third alternative has received little discussion. Yet, focusing on how informed rational clients would bargain and then asking how these results could be duplicated when clients are not able to protect themselves seems the soundest, least controversial starting point from which reform proposals should begin. 